\title{
Structural Style and Kinematic History of the Colombian Eastern Cordillera
}

\author{
Diego Costantino ${ }^{1 *}$, Douglas Paton ${ }^{2}$ and Andrés Mora ${ }^{3}$ \\ ${ }^{1}$ Faculty of Economics, UCES, University of Business and Social Sciences, Buenos Aires, Argentina, ${ }^{2}$ Institute of Applied \\ Geoscience, School of Earth and Environment, University of Leeds, Leeds, United Kingdom, ${ }^{3}$ Ecopetrol Exploration \\ Vicepresidency, Bogotá, Colombia, Ecopetrol-Instituto Colombiano Del Petroleo (ICP), Santander, Colombia
}

\section{OPEN ACCESS}

Edited by:

Fabien Graveleau,

Université De Lille, France

Reviewed by:

Cesar Witt,

Université De Lille, France

Nicholas Perez,

Texas A\&M University, College

Station, United States

*Correspondence:

Diego Costantino

diego.costantino@live.co.uk

Specialty section:

This article was submitted to Structural Geology and Tectonics,

a section of the journal

Frontiers in Earth Science

Received: 01 December 2020

Accepted: 17 February 2021

Published: 01 April 2021

Citation:

Costantino D, Paton D and Mora A (2021) Structural Style and Kinematic

History of the Colombian

Eastern Cordillera.

Front. Earth Sci. 9:636458

doi: $10.3389 /$ feart.2021.636458
Fold-and-thrust belts and their associated structures are among the most common geological features of convergent margins. They provide significant information about crustal shortening and mountain-building processes. In subaerial belts, where the erosional rates are high and the growth strata are mostly eroded, methodologies such as that presented here can provide insights into to their formation. Two 2D cross-sections located in the Eastern Cordillera of Colombia are presented in this research. These sections extend from the Bogota Savanna to The Llanos, parallel to the regional deformation direction. Section construction was carried out using commercial surface data, and seismic information provided by Ecopetrol. Published thermochronometric data, gravel-clast petrography analysis, and paleoflora analysis were used to construct a viable tectono-evolutionary history of the study area. This evolutionary model is presented here in two palinpastic restorations from the Early Paleogene to Recent ( 65 Ma to Present-day). Section 1 and Section 10 accumulated $17.3 \mathrm{~km}$ and $19.5 \mathrm{~km}$ of shortening, respectively. The section reconstruction displays two major tectonic events - post-rift subsidence during the Early-Mid Paleogene, and positive inversion from the Oligocene to Recent ( $33 \mathrm{Ma}$ to Present-day). This investigation focuses on the compressional period, where the structural analysis evidences an acceleration in the shortening rate, as well as a progressive migration of the deformation from northwest to southeast. This research discusses the extent and limitation of this methodology, as well as the principal structural aspects of the reconstruction.

Keywords: structural restoration, thermochronology, deformation rate analysis, kinematic evolution, Eastern Cordillera of Colombia

\section{INTRODUCTION}

Fold-and-thrust belts are the typical place in which shortening is accommodated in the crust, and they are widely distributed (Nemcok et al., 2005; Cooper, 2007). For hydrocarbon exploration, the knowledge of the structural evolution of the fold-and-thrust bels is critical to understand the generation, migration, and accumulation of oil and gas (e.g., Masini et al., 2011).

Two balanced cross-sections were constructed in the Eastern Cordillera of Colombia based on detailed maps, surface and well dips, and confidential seismic data. These cross-sections are in the east portion of the Eastern Cordillera, between latitude $5.60^{\circ} \mathrm{N}$ and $4.00^{\circ} \mathrm{N}$, and longitude $74.30^{\circ} \mathrm{W}$ and $72.60^{\circ} \mathrm{W}$ (Figure 1). For dating thrust events, a wide range of methods can be applied. The timing of thrusting, and associated folding, is best determined when pre-kinematic, syn-kinematic, and post-kinematic depositional sequences are preserved in the study area. Furthermore, when the 


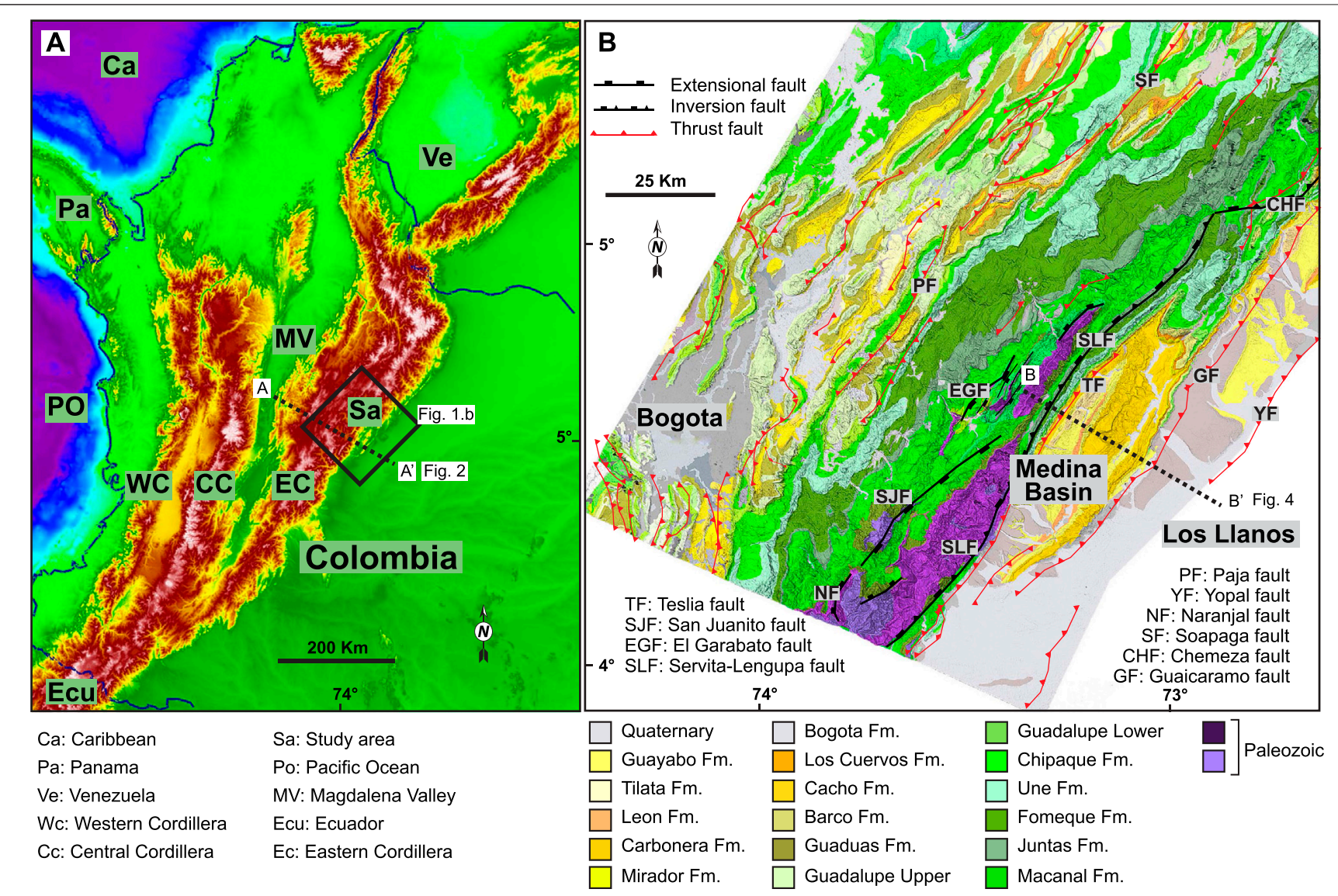

FIGURE 1 | Regional Digital Elevation Model (DEM), and detailed geological map of the study area. (A) Principal tectonic elements of the North Andes with location of the study area. (B) Structural and stratigraphic map of the study area (modified from Parra et al., 2009a).

syn-kinematic deposits (i.e., growth strata) are well recorded, not only the timing, but also the folding mechanism can be recognized in detail (Suppe and Medwedeff, 1990; Erslev, 1991; Poblet et al., 1997; Shaw et al., 2005). This approach has been used in numerous studies in deep-water fold-and-thrust belts (e.g., Bilotti et al., 2005; Rowan and Peel, 2005; Vidal-Royo et al., 2013; Butler, 2020). However, in subaerial belts, where the erosional rates are high, and the growth strata are mostly eroded, as in the Eastern Cordillera, different methods can provide insight into the structural evolution.

Both balanced cross-sections were restored from the Early Paleogene to Recent ( $65 \mathrm{Ma}$ to Present-day). The kinematic evolution of these cross-sections was time-calibrated by means of thermochronometric data, and the chronostratigraphy of the syntectonic successions shaped by the contractional tectonic regime. The necessary topographic surfaces for each restoration stages were inferred from published paleoflora analysis (Wijninga, 1996; Hooghiemstra et al., 2006; Anderson et al., 2016). The structural analysis of these two cross-sections allowed for the understanding of the strain distribution and shortening rate in the study area.

This study focuses on the structural evolution of a portion of the Eastern Cordillera by a comprehensive and multidisciplinary methodology. It analyses the extent and limitation of this methodology, compares the most relevant results with previous researches, and discusses the principal structural aspects of the compressional period in this area (from the Oligocene to Recent).

\section{GEOLOGICAL SETTING}

\section{Structural Setting}

The Colombian Andes (Figure 1A) is characterized by three prominent tectonic elements, the Western, Central, and Eastern Cordilleras. The Eastern Cordillera is the easternmost of these orogens, and is the locus of a Triassic to Early Cretaceous rift system possibly associated with the separation of North and South America in the proto-Caribbean (Cooper et al., 1995). Due to the occurrence of compressional structures previous authors (e.g., Colletta et al., 1990; Cooper et al., 1995) attributed the formation of the Eastern Cordillera to an inversion orogeny. More recently, other studies (e.g., Mora and Parra, 2008; Mora A. S. et al., 2013; Tesón et al., 2013; Mora et al., 2015a; Mora et al., 2015b) have provided further evidence to support the idea that the Eastern Cordillera formed by 


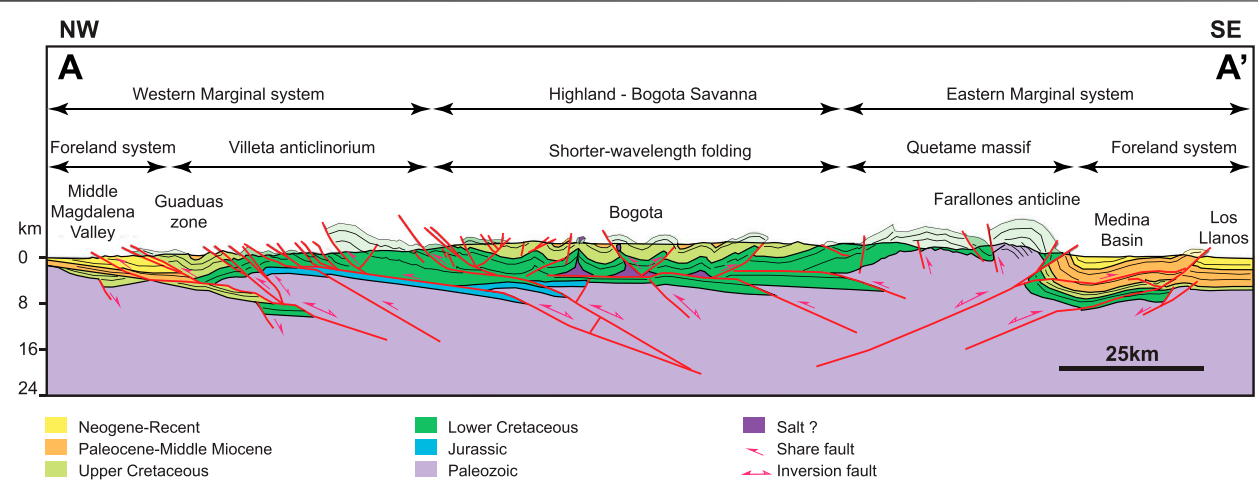

FIGURE 2 | Regional 2D structural cross-section along the Eastern Cordillera of Colombia (modified from Teixell et al., 2015). It is characterized by an overall symmetrical deformation with two marginal systems and a highland in the middle of the section (Bogota Savanna). The inversion-tectonic portion forms a thick-skinned system, whereas the foothill and foreland basin have experienced a thin-skinned deformation.

the inversion of an earlier rift system (involving basement uplift), and a subsequent activation of footwall shortcuts. Inversion onset could be established in the Late Cretaceous (Parra et al., 2012), with an increase in the compressive activity from the Pliocene to Recent, and the active deformation continues to the Present-day (Mora A. et al., 2013).

The study area (Figure 1B) is located between latitude $5.60^{\circ} \mathrm{N}$ and $4.00^{\circ} \mathrm{N}$, and longitude $74.30^{\circ} \mathrm{W}$ and $72.60^{\circ} \mathrm{W}$ (Eastern flank of the Eastern Cordillera). Along the dip direction, this part of the Cordillera displays overall symmetrical deformation (Figure 2), and can be divided into three regions, the Western and Eastern marginal portions, and the Bogota Savanna in the center. The Western and Eastern margins appear to have accommodated the shortening in a brittle manner. In these areas, the inverted structures involve basement uplift that gave rise to thickskinned systems (Figure 2). In contrast, the most marginal areas exhibit thin-skinned tectonics and they are bounded to the East by The Llanos foreland basin and Middle Magdalena Valley intra-mountain basin to the West (Figure 1A and Figure 2). The Bogota Savanna (Figures 1, 2) is located in the highland between the marginal fold-and-thrust belts and is characterized by a low relief that is approximately $2600 \mathrm{~m}$ above sea level (Mora et al., 2008). Unlike the marginal systems, the deformation along this area features shorterwavelength folding with low amplitude. The possible causes of this distinctive deformation are discussed below.

\section{Stratigraphy}

The stratigraphy in the area (Figure 3) can be broadly divided into Paleozoic, Mesozoic, and Cenozoic rocks depicting multiple regional unconformities (Martinez, 2006).

Describing the stratigraphic column from older to younger (Figure 3), the oldest drilled Paleozoic rock is Ordovician (Martinez, 2006). In this study, the Paleozoic rocks are considered the economic basin basement, and the exhumation of this unit resulted in up to $4 \mathrm{~km}$ of low and medium grade metamorphic rocks and intermediate to acid intrusives (Parra et al., 2009b; Segovia, 1965). The Devonian to Carboniferous rocks are deposited disconformably overlying the basement, and they can reach up to $4 \mathrm{~km}$ of thickness. They are formed by clastic platformal sequences described as the Devonian-Carboniferous Farallones Group (Figure 2) located in the Quetame Massif (Ulloa and Rodriguez, 1976).

During the early period of rifting, from the Triassic to Jurassic, the deposition was predominantly volcanoclastic with some intercalation of non-marine to shallow marine sediments (Parra et al., 2009b). These sediments were locally deposited on the narrow asymmetric grabens located mostly in the western flank of the Eastern Cordillera (e.g., Rusia and Giron Formations in Figure 3).

The thickness (approximately 4-6 km) and wide distribution of the Lower Cretaceous rocks, suggest that the Later Mesozoic rifting phase initiated a wider extensional system (Mora et al., 2006; Mora et al., 2009). During this period the basin was bounded by regional extensional faults dipping basinward (La Salina fault to the west and Servita-Lengupa system to the east in Figure 1B). Macanal, Las Juntas, and Fomeque Formations were deposited in the study area during this period (Figure 3).

During the post-rift and thermal subsidence (Sarmiento-Rojas et al., 2006), in the Upper Cretaceous, approximately $1.5-2.0 \mathrm{~km}$ thick sediments were deposited in this basin. They are Une, Chipaque, and Guaduas Formations and Guadalupe Group (Figure 3).

The Late Cretaceous inversion of this Mesozoic rift basin gave rise to a foreland system east of the basin which extends throughout the foothill and The Llanos basin (Bayona et al., 2008; Cooper et al., 1995). The Cenozoic rocks in the Medina Basin (Figure 1B) comprise a Paleocene to Late Miocene sequence which evolves from coastal plain and tidally influence lacustrine sediments of the Barco, Los Cuervos, Mirador, Carbonera, and Leon Formations (Figure 3), to the proximal and alluvial deposits of Guayabo Group (Cooper et al., 1995; Parra et al., 2009b).

\section{METHODOLOGY AND DATA}

The methodology applied in this study covers a number of structural-geology subjects, such as section construction and 


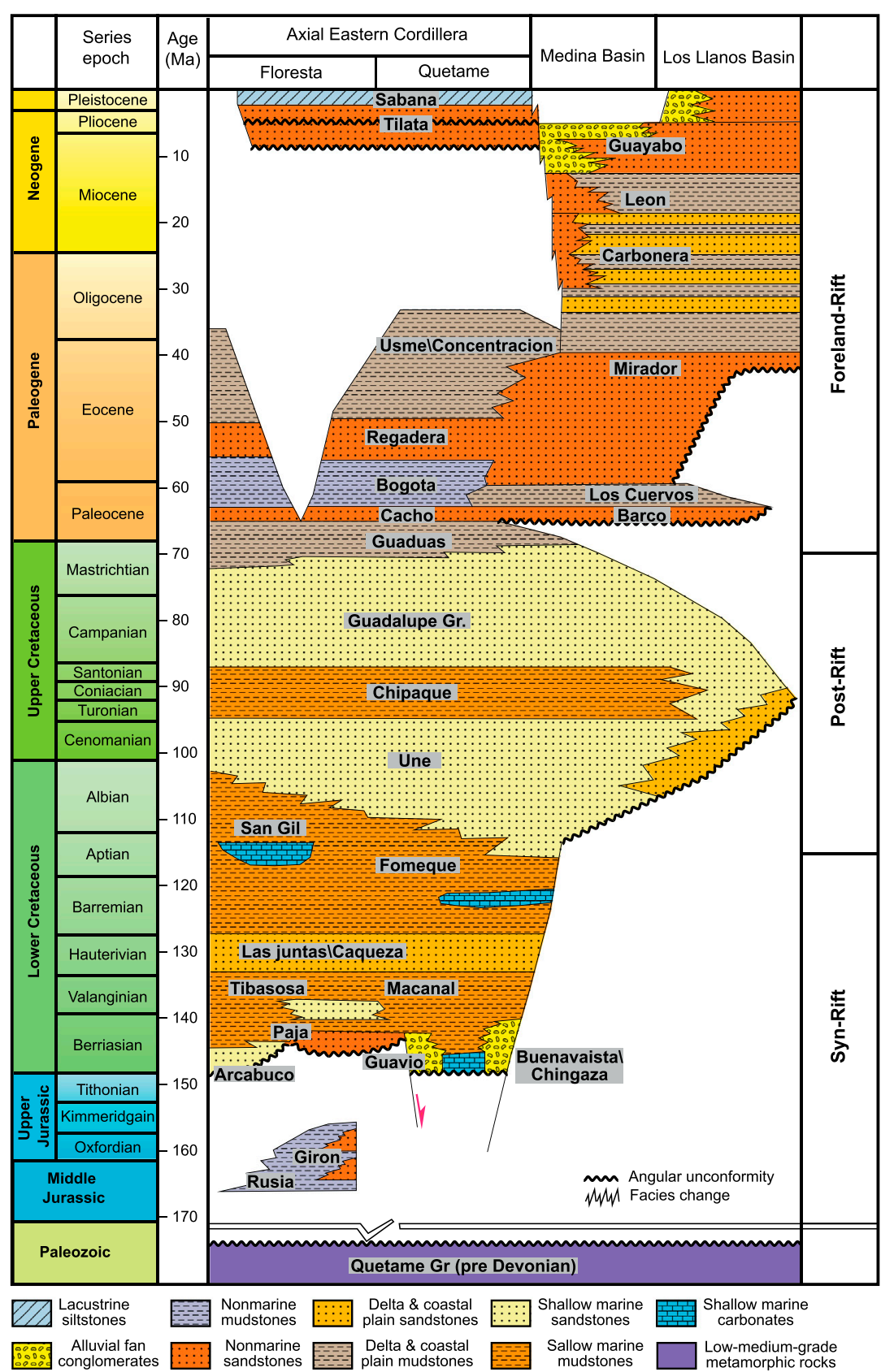

FIGURE 3 | Stratigraphic column of the Eastern part of Eastern Cordillera, Medina, and The Llanos basin (modified from Cooper et al., 1995; Parra et al., 2009a).

balancing, low-temperature thermochronology-based section restoration, and paleotopograhy reconstruction. For this study, Ecopetrol Colombia has provided commercial datasets: 2D seismic reflection, surface dips, geological maps, and well data (formation markers and strata dip). The thermochronology used to constrain the structural evolution has been published by Parra et al. (2009a). The paleotopography construction was carried out based on the paleoaltimetry and paleoflora analysis published by Van der Hammen et al. (1973), Hooghiemstra et al. (2006), and Wijninga (1996); and gravel-clast petrography analysis from the
Medina Basin (Parra et al., 2009b; Parra et al., 2010). This comprehensive method can give insights into the evolution of the fold-and-thrust belts where the growth strata are highly eroded. However, the accuracy of the outcomes is subject to the quantity and quality of the available data.

\section{D Section Construction and Balancing}

The commercial structural modeling and analysis platform, Move $^{\mathrm{TM}}$ of Petroleum Experts Ltd., was primarily used for this 


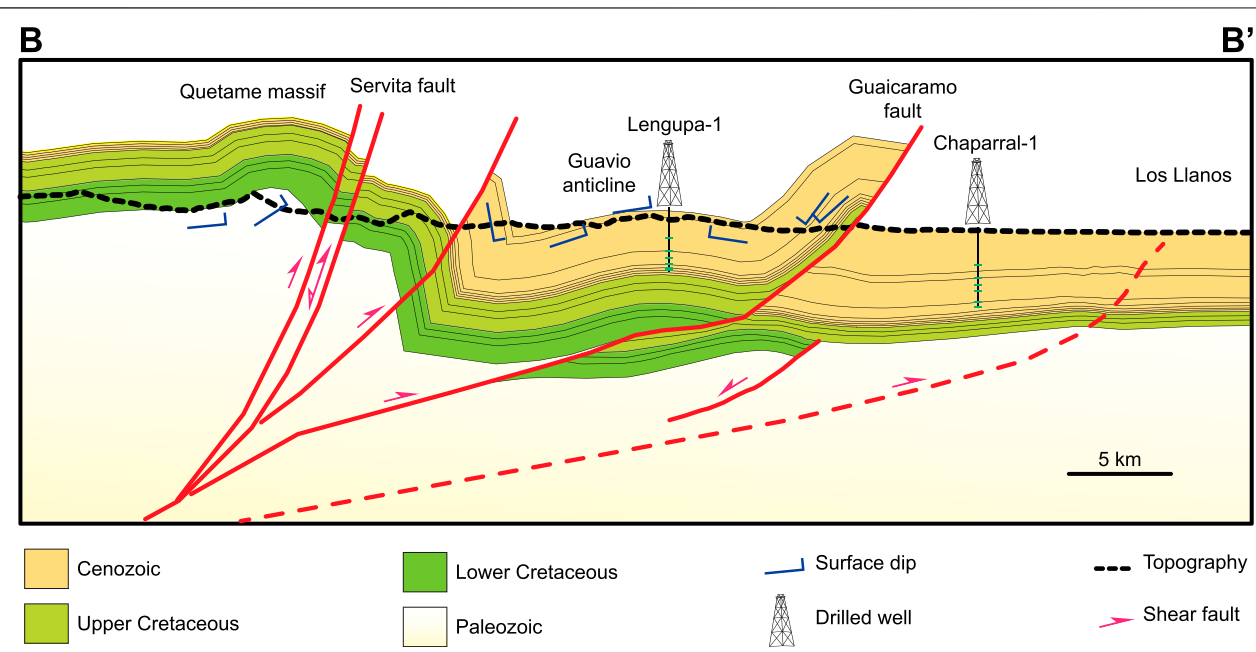

FIGURE 4 | Structural section constructed along the Medina Basin area using the kink method (see location in Figure 1). The principal elements for the section construction are: 2D seismic profiles, geological contacts, surface dips, well markers and dips, and the topographic profile.

study. The 'kink method' (cf. Allmendinger, 2015) was applied for the section construction and balancing.

For the two sections presented in this study, the section construction was carried out by a comprehensive methodology which involves different data from diverse sources. Figure 4 displays an example of section construction and balancing, and the multi-source data involved in this process. The topographic profile on each section (Figure 4) was extracted from the Digital Elevation Model (DEM) available for this research (International Hydrographic Organization, 2003). The intersections of the different formations (Figure 1B) with the topographic profile were calculated projecting the formational contacts of the geological map as displayed in Figure 4. Similar process was used for the fault intersection. Surface dips (Figure 4) were used to constrain the strata dip angles nearby the topographic surface. Limited and confidential 2D seismic reflection and well data were used to interpret the deep structures of the foreland basin; particularly in the Medina Basin and The Llanos where thick layers of recent sediments preclude the use of surface-observation method.

\section{Thermochronometric Dating}

Techniques involving low-temperature thermochronometric dating have been widely used to reveal the exhumation, and its associated cooling history, in many geological settings affected by upper-crust processes (e.g., Garver et al., 1999; Reiners and Brandon, 2006; Blythe et al., 2007). This method allows a correlation between the rock exhumation and the processes that transport rocks to the topographic surface. Methods such as fission track (FT) and (U-Th) He have proven successful in areas where the exhumation occurred during the Late Mesozoic to Cenozoic period; encompassing extensional tectonic settings (e.g. Armstrong et al., 2003; Ehlers et al., 2003; Blythe et al., 2007), and compressional systems such as subduction zones and collisional belts (e.g., Garver and Kamp, 2002; Ehlers et al., 2003; Garver et al., 2005; Cao et al., 2013). Specifically, in the
Easter Cordillera, this technique has allowed for significant advancement of understanding about how the Eastern Cordillera formed (e.g., Parra et al., 2009b; Mora et al., 2010; Parra et al., 2012; Mora A. S. et al., 2013; Cao et al., 2013; Carrillo et al., 2016).

Thermochronometric dating does not provide structuralevolution information per se, but the thermal history of an exhumed sample. However, the temperature variation of a sample that has been buried relates to the exhumation of this sample (Fitzgerald et al., 1995; Lisker et al., 2009). Moreover, exhumation can be described as the displacement of rocks with respect to the topographic surface (England and Molnar, 1990). Therefore, exhumation cannot be simply associated with an uplift rate; but to a more sophisticated process - denudation. Erosion or tectonics (and a combination of both) generate denudation at the Earth's surface. Erosion is the process by which soil or rock experience breaking down, chemical solution and transport (Michael, 2008); whereas tectonic denudation is associated with extension and normal faulting resulting in a rapid removal of large rock volumes (Lisker et al., 2009). Due to the variety of processes associated with the thermal history of a sample, it is necessary to constrain this information with geological data to obtain a verisimilar solution in terms of structural evolution (i.e., uplift, folding, and transport rate). In this research the thermochronometric data from apatite and zircon fission tracks are combined with paleoelevation and paleoprovenance studies to sequentially restore the deformation in the study area.

The fission track method is based on the fission decay of uranium which forms a linear damage trace in the mineral lattice (Fleischer et al., 1975). The fission track traces form continuously at relative low temperature, but they are annealed rapidly if the mineral experiences high temperature. During the annealing process, the damage traces reduce the length until they vanish away; therefore, the previous thermal history is reset. Subsequently, if the annealed sample is brought to 


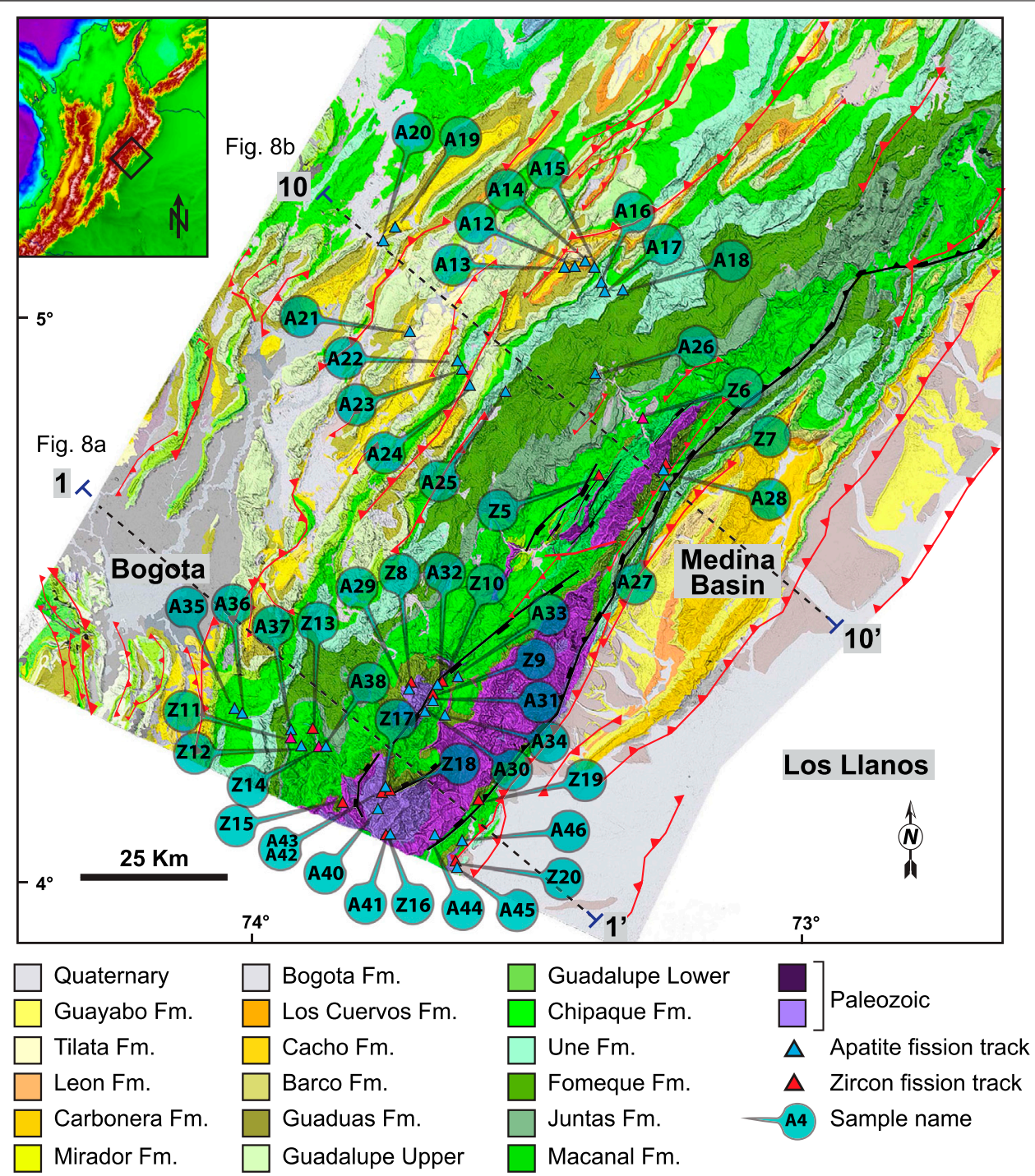

FIGURE 5 | Geological map with the apatite and zircon fission track sample distribution, and the trace of the two cross-sections restored in this study.

temperatures below the annealing temperature, fission tracks forms over again recording a new thermal history. For apatite, the temperature of continuous annealing (or closure temperature) is approximately $100-120^{\circ} \mathrm{C}$, and for zircon it is approximately $250-300^{\circ} \mathrm{C}$ (Green et al., 1986). A relevant aspect to consider about this method is that there is a range of temperature of partial annealing, the "partial annealing zone" (PAZ). Within the PAZ the annealing process intensifies rapidly when the temperature increases. Conventional ranges of PAZ from $\sim 60-120^{\circ} \mathrm{C}$ and $\sim 210-300^{\circ} \mathrm{C}$ are estimated for apatite and zircon respectively (Green et al., 1986; Tagami, 2005). If a sample experiences slow transit through the PAZ, the annealing process would affect the tracks length precluding a confidence analysis. In orogenic belts, which have experienced rapid cooling due to uplift and erosion, such as the Eastern Cordillera, a characteristic fission-track profile should be recorded.
The geographic distribution of the apatite and zircon fissiontrack samples used for this study is shown in Figure 5. These 49 samples have been analyzed by Parra et al. (2009a) to study the diachronous exhumation of the Central and Eastern Cordillera. Table 1 presents the fission track ages with their corresponding formation. Further details regarding the sample analyses are presented in Parra et al. (2009a) Tables 1, 2, and its respective auxiliary material.

\section{Paleotopographic Restoration}

In this study the sequential structural restoration has been carried out by the analysis of the exhumation history of a series of fission-track samples. As mentioned above, exhumation can be defined as the displacement of a portion of rock with respect to the topographic surface (England and Molnar, 1990). Thereby, the reconstruction of paleotopographies becomes crucial for the process of relating exhumation and cooling 
TABLE 1 | Apatite and zircon fission track samples used for this research (modified from Parra et al., 2009a).

\begin{tabular}{|c|c|c|c|c|c|c|}
\hline Name & Formation & Longitude & Latitude & Elevation & Age & Sigma \\
\hline A12 & $\begin{array}{l}\text { Picacho } \\
\text { formation }\end{array}$ & -73.4379 & 5.2185 & 2097 & 11.7 & 1.7 \\
\hline A13 & $\begin{array}{l}\text { Upper socha } \\
\text { formation }\end{array}$ & -73.4253 & 5.2207 & 2025 & 38.3 & 3.5 \\
\hline A14 & $\begin{array}{l}\text { Upper socha } \\
\text { formation }\end{array}$ & -73.4079 & 5.2301 & 1901 & 52.5 & 3.4 \\
\hline A15 & $\begin{array}{l}\text { Guadalupe } \\
\text { group }\end{array}$ & -73.3954 & 5.2210 & 1928 & 21.2 & 2.7 \\
\hline A16 & Une formation & -73.3820 & 5.1928 & 1711 & 5.3 & 1.4 \\
\hline A17 & Une formation & -73.3744 & 5.1792 & 1884 & 10.4 & 1.3 \\
\hline A18 & Une formation & -73.3427 & 5.1840 & 2396 & 10.2 & 2.8 \\
\hline A19 & $\begin{array}{l}\text { Upper socha } \\
\text { formation }\end{array}$ & -73.7582 & 5.2712 & 2595 & 45.9 & 2.2 \\
\hline A20 & $\begin{array}{l}\text { Cacho } \\
\text { formation }\end{array}$ & -73.7660 & 5.2583 & 2600 & 17.6 & 2.0 \\
\hline A21 & $\begin{array}{l}\text { Guadalupe } \\
\text { group }\end{array}$ & -73.7150 & 5.1079 & 2630 & 24.4 & 3.1 \\
\hline A22 & Une formation & -73.6294 & 5.0518 & 2275 & 14.6 & 3.7 \\
\hline A23 & Une formation & -73.6261 & 5.0424 & 2255 & 9.7 & 1.4 \\
\hline A25 & Une formation & -73.5496 & 5.0026 & 1868 & 5.4 & 3.1 \\
\hline A26 & $\begin{array}{l}\text { Las juntas } \\
\text { formation }\end{array}$ & -73.3907 & 5.0321 & 1341 & 1.9 & 0.7 \\
\hline A27 & $\begin{array}{l}\text { Bata } \\
\text { formation }\end{array}$ & -73.2680 & 4.8640 & 851 & 1.7 & 0.4 \\
\hline A28 & $\begin{array}{l}\text { Farallones } \\
\text { group }\end{array}$ & -73.2670 & 4.8730 & 990 & 2.2 & 0.4 \\
\hline A29 & $\begin{array}{l}\text { Chingaza } \\
\text { formation }\end{array}$ & -73.7310 & 4.4880 & 3660 & 2.7 & 0.7 \\
\hline A30 & $\begin{array}{l}\text { Quetame } \\
\text { group }\end{array}$ & -73.7080 & 4.4600 & 2866 & 2.4 & 0.7 \\
\hline A31 & $\begin{array}{l}\text { Quetame } \\
\text { group }\end{array}$ & -73.6930 & 4.4720 & 2251 & 2.3 & 0.8 \\
\hline A32 & $\begin{array}{l}\text { Quetame } \\
\text { group }\end{array}$ & -73.6810 & 4.4940 & 2748 & 2.8 & 0.4 \\
\hline A33 & $\begin{array}{l}\text { Buenavista } \\
\text { formation }\end{array}$ & -73.6570 & 4.4950 & 1893 & 0.8 & 0.3 \\
\hline A34 & $\begin{array}{l}\text { Macanal } \\
\text { formation }\end{array}$ & -73.6800 & 4.4300 & 1630 & 1.2 & 0.4 \\
\hline A35 & $\begin{array}{l}\text { Chipaque } \\
\text { formation }\end{array}$ & -74.0207 & 4.4427 & 2275 & 13.8 & 2.6 \\
\hline A36 & $\begin{array}{l}\text { Chipaque } \\
\text { formation }\end{array}$ & -74.0094 & 4.4349 & 2022 & 14.3 & 3.8 \\
\hline A37 & $\begin{array}{l}\text { Cáqueza } \\
\text { formation }\end{array}$ & -73.9543 & 4.3979 & 2123 & 2.0 & 0.7 \\
\hline A38 & $\begin{array}{l}\text { Macanal } \\
\text { formation }\end{array}$ & -73.9010 & 4.3700 & 1451 & 3.8 & 0.7 \\
\hline A40 & $\begin{array}{l}\text { Quetame } \\
\text { group }\end{array}$ & -73.8000 & 4.2670 & 942 & 1.6 & 0.4 \\
\hline A41 & $\begin{array}{l}\text { Quetame } \\
\text { group }\end{array}$ & -73.7950 & 4.2030 & 2224 & 2.3 & 0.6 \\
\hline A42 & $\begin{array}{l}\text { Quetame } \\
\text { group }\end{array}$ & -73.7830 & 4.2930 & 2862 & 2.6 & 1.1 \\
\hline A43 & $\begin{array}{l}\text { Quetame } \\
\text { group }\end{array}$ & -73.7830 & 4.2930 & 2905 & 2.6 & 0.5 \\
\hline A44 & $\begin{array}{l}\text { Farallones } \\
\text { group }\end{array}$ & -73.7120 & 4.1960 & 857 & 2.9 & 2.1 \\
\hline A45 & $\begin{array}{l}\text { Buenavista } \\
\text { formation }\end{array}$ & -73.6690 & 4.1620 & 870 & 2.6 & 0.3 \\
\hline A46 & $\begin{array}{l}\text { Buenavista } \\
\text { formation }\end{array}$ & -73.6450 & 4.1990 & 617 & 3.0 & 0.4 \\
\hline Z05 & $\begin{array}{l}\text { Macanal } \\
\text { formation }\end{array}$ & -73.3844 & 4.8534 & 1858 & 15.7 & 1.5 \\
\hline
\end{tabular}

TABLE 1 | (Continued) Apatite and zircon fission track samples used for this research (modified from Parra et al., 2009a).

\begin{tabular}{|c|c|c|c|c|c|c|}
\hline Name & Formation & Longitude & Latitude & Elevation & Age & Sigma \\
\hline Z06 & $\begin{array}{l}\text { Macanal } \\
\text { formation }\end{array}$ & -73.3130 & 4.9586 & 1428 & 17.9 & 1.0 \\
\hline ZO7 & $\begin{array}{l}\text { Farallones } \\
\text { group }\end{array}$ & -73.2673 & 4.8732 & 990 & 24.9 & 1.4 \\
\hline Z08 & $\begin{array}{l}\text { Chingaza } \\
\text { formation }\end{array}$ & -73.7312 & 4.4885 & 3660 & 13.1 & 0.9 \\
\hline Z09 & $\begin{array}{l}\text { Quetame } \\
\text { group }\end{array}$ & -73.6931 & 4.4716 & 2251 & 11.5 & 0.6 \\
\hline Z10 & $\begin{array}{l}\text { Quetame } \\
\text { group }\end{array}$ & -73.6809 & 4.4938 & 2748 & 5.9 & 0.4 \\
\hline Z11 & $\begin{array}{l}\text { Caqueza } \\
\text { formation }\end{array}$ & -73.9530 & 4.3968 & 2090 & 136.5 & 13.4 \\
\hline Z12 & $\begin{array}{l}\text { Macanal } \\
\text { formation }\end{array}$ & -73.9270 & 4.3627 & 2382 & 61.3 & 6.4 \\
\hline Z13 & $\begin{array}{l}\text { Macanal } \\
\text { formation }\end{array}$ & -73.9087 & 4.3772 & 1582 & 13.3 & 1.0 \\
\hline Z14 & $\begin{array}{l}\text { Macanal } \\
\text { formation }\end{array}$ & -73.9010 & 4.3705 & 1451 & 18.5 & 1.0 \\
\hline Z15 & $\begin{array}{l}\text { Quetame } \\
\text { group }\end{array}$ & -73.8346 & 4.2789 & 1226 & 8.3 & 0.5 \\
\hline Z16 & $\begin{array}{l}\text { Quetame } \\
\text { group }\end{array}$ & -73.795 & 4.2029 & 2224 & 9.0 & 0.5 \\
\hline Z17 & $\begin{array}{l}\text { Quetame } \\
\text { group }\end{array}$ & -73.7834 & 4.2925 & 2862 & 11.4 & 1.1 \\
\hline Z18 & $\begin{array}{l}\text { Chingaza } \\
\text { formation }\end{array}$ & -73.7771 & 4.2976 & 3084 & 9.8 & 0.6 \\
\hline Z19 & $\begin{array}{l}\text { Buenavista } \\
\text { formation }\end{array}$ & -73.6091 & 4.2796 & 1096 & 145.2 & 17.3 \\
\hline Z20 & $\begin{array}{l}\text { Buenavista } \\
\text { formation }\end{array}$ & -73.6690 & 4.1624 & 870 & 165.9 & 12.9 \\
\hline
\end{tabular}

TABLE 2 | Accumulative shortening in the study area.

\begin{tabular}{lccc}
\hline Age (Ma) & Section 1 (km) & Section $\mathbf{1 0}(\mathbf{k m})$ & Agerage (km) \\
\hline 33 & 0 & 0 & 0 \\
23 & 0.65 & 3 & 1.8 \\
11 & 2.38 & 4.6 & 3.5 \\
5 & 4.46 & 10.5 & 7.5 \\
3 & 9.82 & 14.5 & 12.2 \\
0 & 17.3 & 19.5 & 18.4 \\
\hline
\end{tabular}

history to uplift and erosion. A paleotopography can be modeled by means of indirect methods, and can be subject to significant errors and uncertainty depending on the quantity and quality of the data involved in the process. In this research the paleotopographies were inferred based on published analysis of paleoaltimetry and paleoflora for the axial zone and Bogota Savanna (Wijninga, 1996; Hooghiemstra et al., 2006), and lipid biomarker analysis (Anderson et al., 2015; Anderson et al., 2016).

Paleoaltimetry and paleoflora: these methods have been used previously in the Eastern Cordillera to gain understanding about the structural evolution of this orogen (e.g., Hooghiemstra and Cleef, 1995; Hooghiemstra et al., 2006; Torres et al., 2005; Veer and Hooghiemstra, 2000). This 


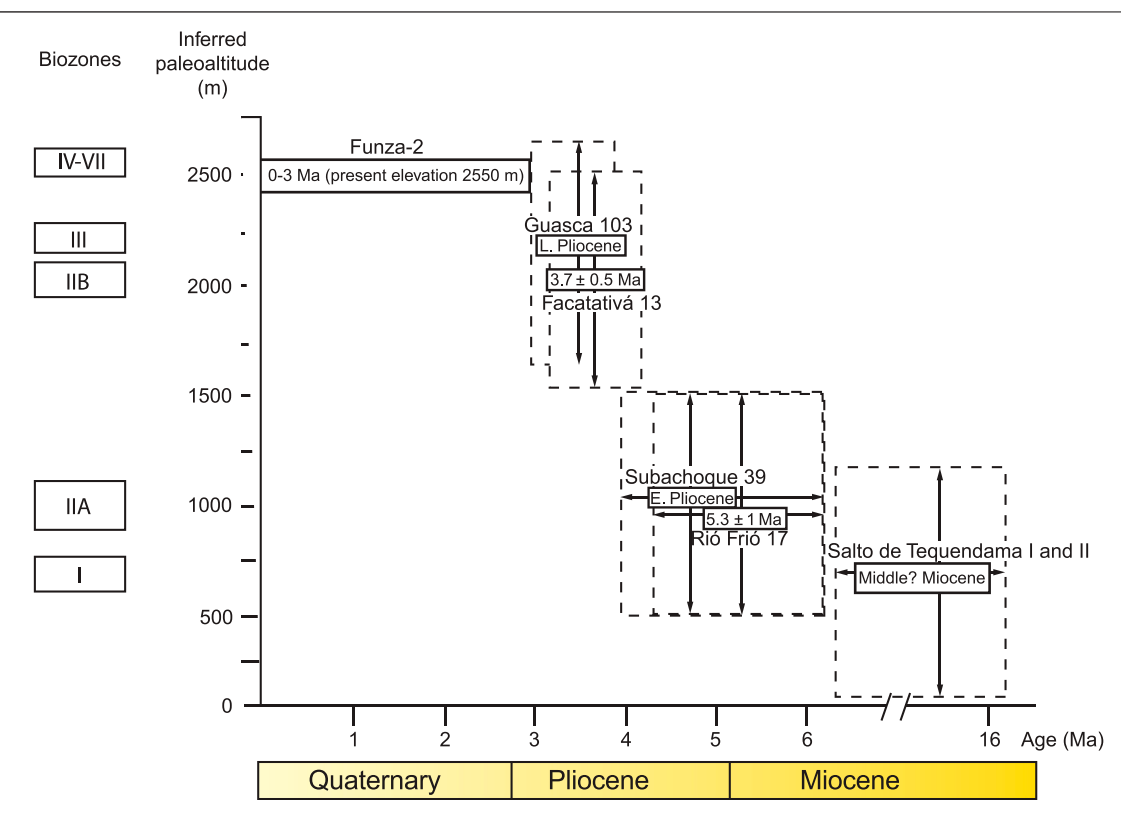

FIGURE 6 | Paleoaltimetry estimations based on fossil pollen spectra analysis for the Bogota Savanna and surrounding areas (modified from Hooghiemstra et al., 2006; Wijninga, 1996).

methodology allows the correlation between fossil pollen spectra with similar pollen spectra from modern vegetation. Figure 6 summarizes the fossil flora analysis conducted by Hooghiemstra et al. (2006), and Wijninga (1996), in the Late Miocene to Late Pliocene fluvialite Tilata Formation, from samples collected in the Bogota Savanna. They argue that for the Middle Miocene the paleoelevation in the Bogota Savanna region was $\sim 700 \pm 400 \mathrm{~m}$, during the early Pliocene $\sim 1100 \pm$ $400 \mathrm{~m}$, in the Late Pliocene $\sim 2000 \pm 400 \mathrm{~m}$, and for the Quaternary $\sim 2500 \mathrm{~m}$ - which is the Present-day average of elevation in this region. This information has been previously used in the same fashion in the Eastern Cordillera to calibrate thermochronometric restorations (e.g., Wijninga, 1996; Mora A. S. et al., 2013; Carrillo et al., 2016).

More recently, the chronology of deposition of those units and the paleoelevaton estimations have been reassessed by Anderson et al. (2015); however, the results essentially confirm those by Wijninga (1996).

\section{Provenance Analysis and Unroofing History}

The gravel-clast petrography analysis allows the temporal and spatial correlation of eroded and transported sediments with their final depositional area. Foreland basins are generally formed as a result of flexural subsidence which is driven by the thrust-sheet loading affecting the frontal system (DeCelles and Giles, 1996). Therefore, the sediments deposited in the accommodation space of the foreland basin derive principally from the frontal-system erosion (Dickinson and Suczek, 1979; DeCelles and Giles, 1996). Hence, the gravel-clast petrography analysis of a foreland basin permits the reconstruction of the erosion windows on the paleoprovenance areas. Parra et al. (2010) tracked the occurrence of different conglomerate clasts deposited in the Medina Basin during the Oligocene-Miocene to evaluate the unroofing history of the exposed Quetame massif (Figure 7). They interpreted a normal unroofing sequence suggesting that Paleogene rocks are the sources of the conglomerates below the Upper C1 Member; and the sources of the Upper C1 Member, Leon, and Guayabo Formations are Upper Cretaceous rocks (Guadalupe, Chipaque, and Une Formations). In this research, this information is used to calibrate the paleotopography reconstruction in the frontal system and adjacent areas (Quetame massif, Medina Basin, and the proximal part of The Llanos). Even more, it is necessary to recreate the erosion windows in the frontal system that contributed to the depositional record in the Medina Basin.

\section{Paleocurrents and the Age of the Guavio Anticline}

The Guavio anticline is a thin-skin structure that is bounded by the Guaicaramo fault to the southeast (Figure 4). Seismic data suggest that the Guavio anticline is a fault bend fold related to the subsurface shape of Guaicaramo fault. If that is the case, the age of the Guavio anticline would be directly associated with the age of the Guaicaramo fault. This fault cuts through the Neogene and Quaternary sedimentary units in The Llanos foreland (Figure 4). There are also active terraces related to this fault (Mora et al., 2010). Therefore, it should have been active most likely from the latest Neogene throughout the Quaternary. However, Quintero (2010) documented a significant shift in paleocurrents in the Neogene sedimentary units in the Guavio anticline, from dominantly parallel to the structural grain to perpendicular 

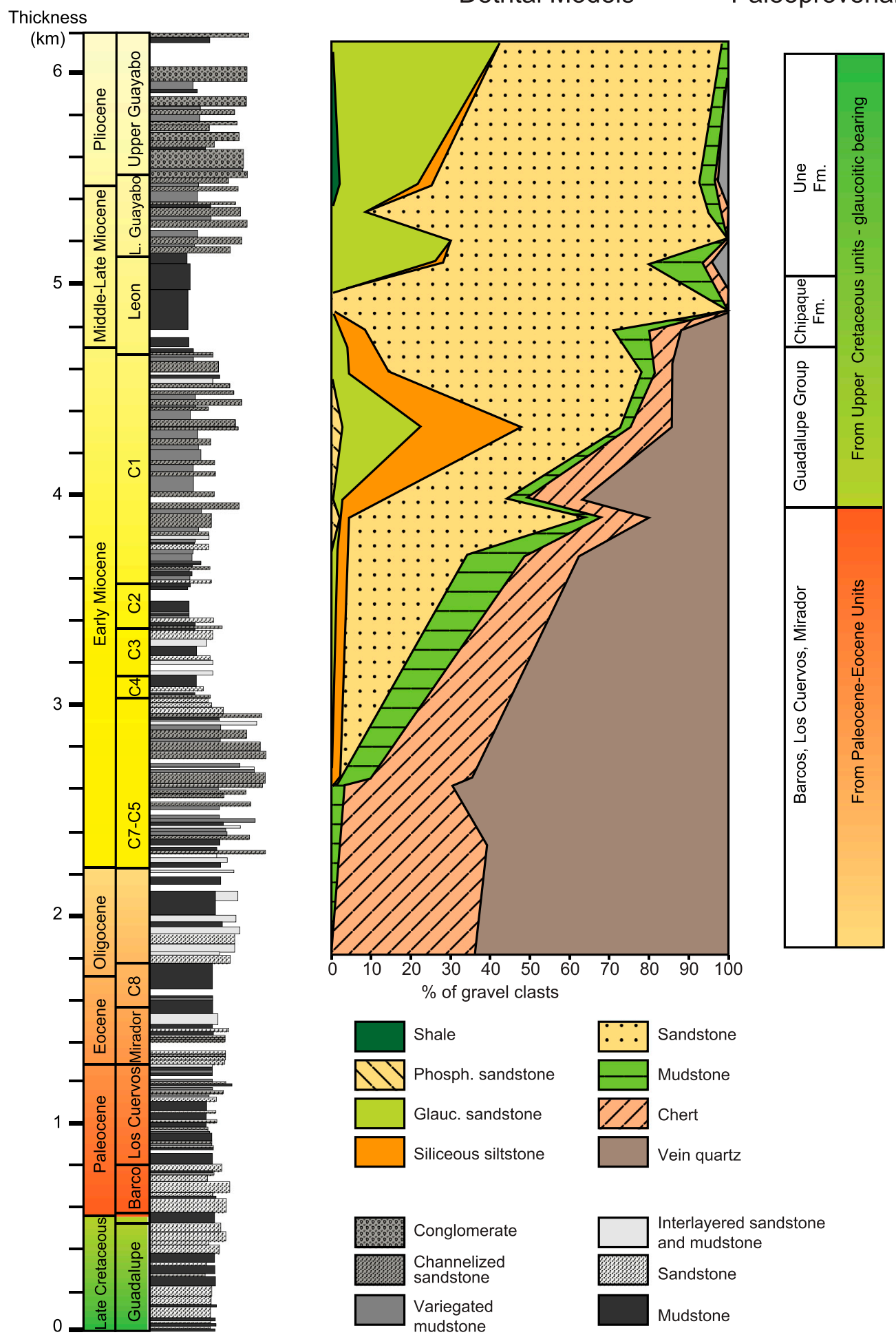

FIGURE 7 | Gravel-clast petrography analysis of the Medina Basin (modified from Parra et al., 2010).

and pointing to the NW. This shift was observed by Quintero (2010) in the uppermost Miocene units. Therefore, the most evident growth of the Guavio anticline can be bracketed between Late Miocene and the Present-day. Uncertainties would be related to the age of the sedimentary units where the paleocurrents were measured (Quintero, 2010). 


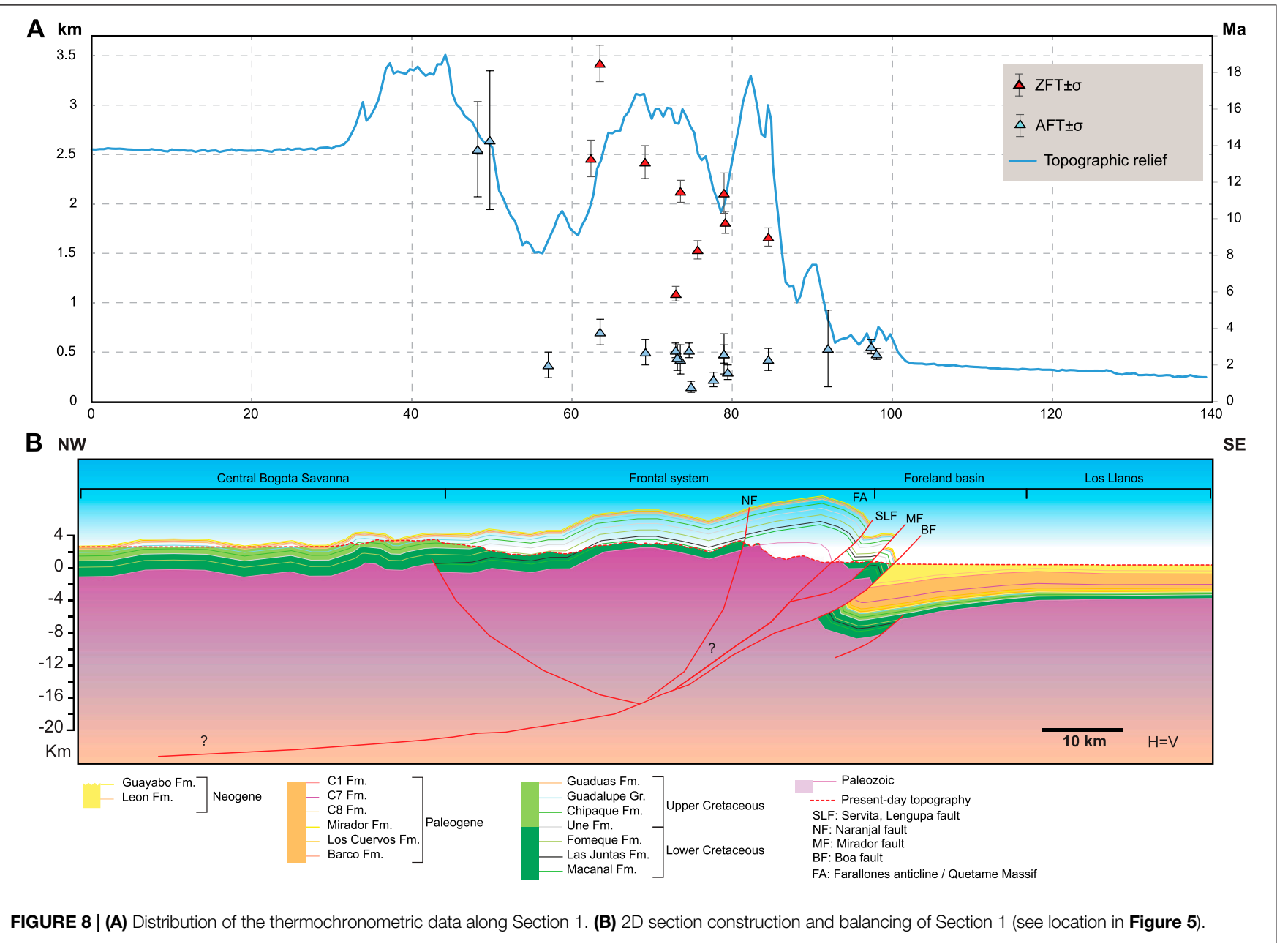

\section{D Thermokinematic Restoration}

The integration of the above-mentioned techniques and data sets was used to constrain the restoration at different times for both cross-sections. The restorations have to respect different assumptions like the following.

Thermochronology would guide at which temperature the different rock units should be for the restoration steps. While this happens, the unroofing history from gravel petrography would limit which units are exposed and shedding detritus at the surface. Therefore, the still buried and hot rocks in the subsurface (and their thicknesses) should be coherent with the actively eroding and exposed rock units and, more important, should not be the same. For example, while the actively eroding units at a particular time are at the surface, thermochronometers may predict that other units should be $4 \mathrm{~km}$ underneath the topography. Thus, the calculated thicknesses for the different rock units, which is still buried and preserved, should respect both data sets.

Finally, the paleoelevation estimates would allow to approximately constrain the maximum elevation above the sea level where the exposed rock units could be. This should be in agreement with the predicted fault geometries at depth, and the structural and topographic elevation where the rocks should be exposed. Thus, the above-mentioned data relate denudation, rocks, and surface uplift in a single structural restoration. If the available data for this study area are carefully used, the deformation of the different rock units would be constrained with reasonable accuracy.

\section{RESULTS}

The 2D section construction, balancing (Figures 8, 9), and restoration (Figure 10) of Section 1 and 10 are discussed here. It was possible to obtain nine evolutionary stages from the thermochronology constraints. These evolutionary stages can be broadly divided in two major tectonic events: post-rift, and inversion tectonics. The Cretaceous rift period was followed by a post-rift regime characterized by cooling and subsidence. From $\sim 65 \mathrm{Ma}$ to $\sim 40 \mathrm{Ma}$ (Early Paleocene to Late Eocene) the post-rift tectonics facilitated the accommodation space for the deposition of the following Paleogene units: Guaduas Formation at $65 \mathrm{Ma}$ (Figures 10A,B), Los Cuevos Formation at $\sim 55 \mathrm{Ma}$ (Figures 10C,D), Mirador Formation at 


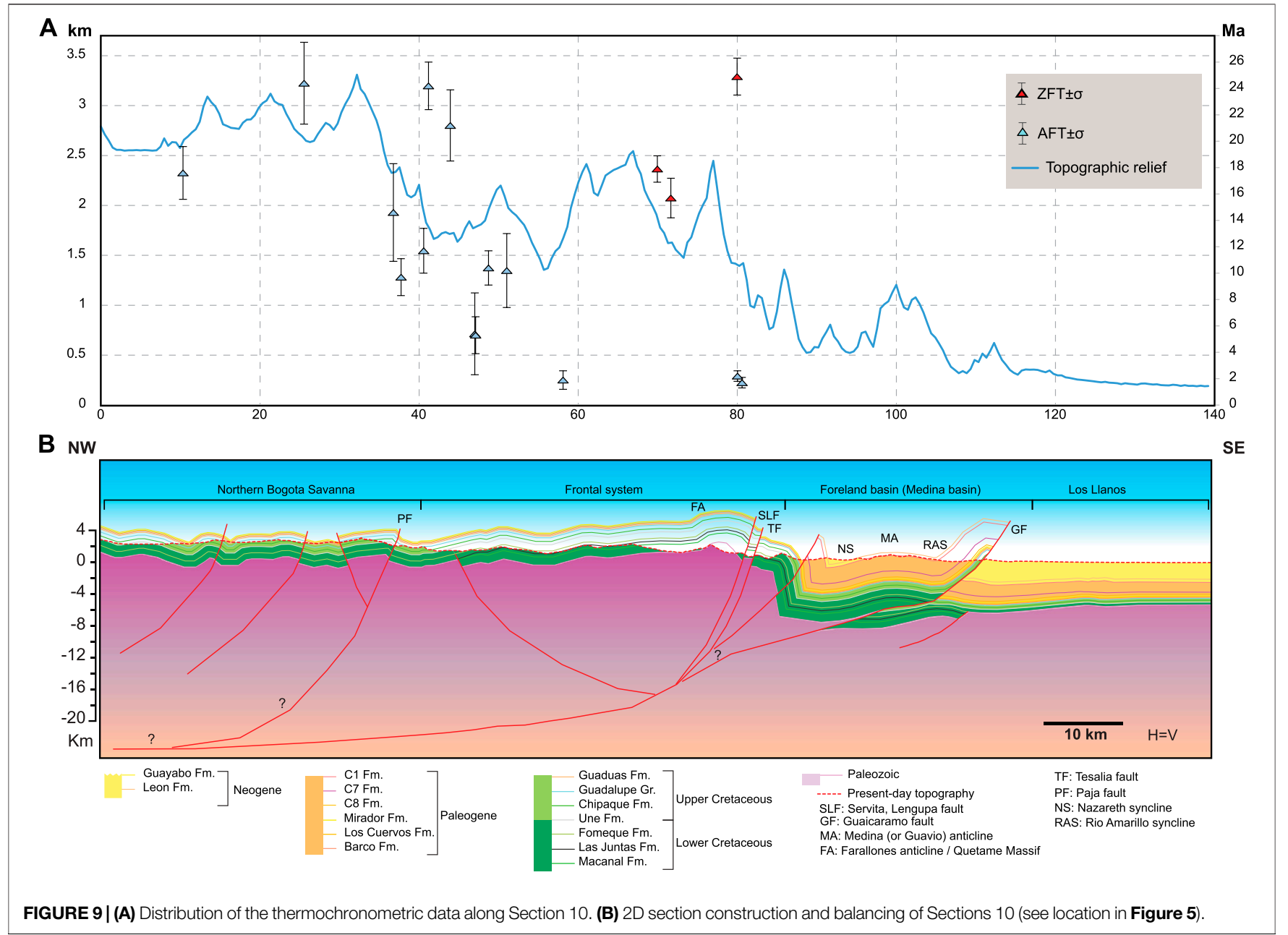

$\sim 40 \mathrm{Ma}$ (Figures 10E,F). From $\sim 33 \mathrm{Ma}$ to Recent (Figures 10G-R) the study area experienced positive inversion tectonics characterized by a compressive deformation which initiated in the northwest and propagated toward the southeast. First, the structural style of the balanced crosssections; and second, the structural evolution of this portion of the Eastern Cordillera are described as follows.

\section{Structural Style}

One of the principal structural features of this area is the coexistence of thick and thin-skinned deformations (Figures $\mathbf{8}, \mathbf{9})$. In the Eastern Cordillera, from the Servita-Lengupa fault toward the hinterland, a thick-skinned deformation with basement uplift caused by the inversion tectonic initiated during the Oligocene is observed, and also documented in previous works (e.g., Horton et al., 2010; Ramirez-Arias et al., 2012). Farther to the Southeast, in Medina Basin (Figure 9), the occurrence of shallower detachments associated with thrust ramps results in a thin-skinned deformation of more recent age.

The hinterland of the study area is the locus of a high plateau (cf. Ramirez-Arias et al., 2012), known as Bogota Savanna
(Figures 8, 9). Section 1 and 10 run along the middle and northeast of this structural elevation respectively (Figure 5). Paradoxically, the degree of deformation on this plateau is significantly less than in the foreland system; however, the plateau is in a much higher structural position. A possible cause of the plateau uplift is discussed below.

From the Bogota Savanna toward the fontal system (Figures $\mathbf{8}, \mathbf{9})$ the most important structural and topographic relief is observed. This deformation is associated with the external inversion faults (Servita-Lengupa, and Tesalia faults) which accommodate the thick-skinned displacement. Farther to the foreland (i.e., to the southeast) the foreland basin is disrupted by a series of low-angle $\left(\sim 30^{\circ}\right)$ thrust faults (Mirador and Boa fault in Section 1, and Guaicaramo fault in Section 10) which give rise to a thin-skinned system. They are interpreted as footwall edge shortcuts (cf. Mora and Parra, 2008; Rowan and Linares, 2000; Tesón et al., 2013) connected to the aforementioned inversion faults (Figures 8, 9). In the case of the Guaicaramo fault, it can be described as a multi-ramp thrust with a sub-horizontal segment in between. The Medina (or Guavio) anticline in the foreland basin in Section 10 (Figure 9) is the consequence of a fault-bend-folding deformation 


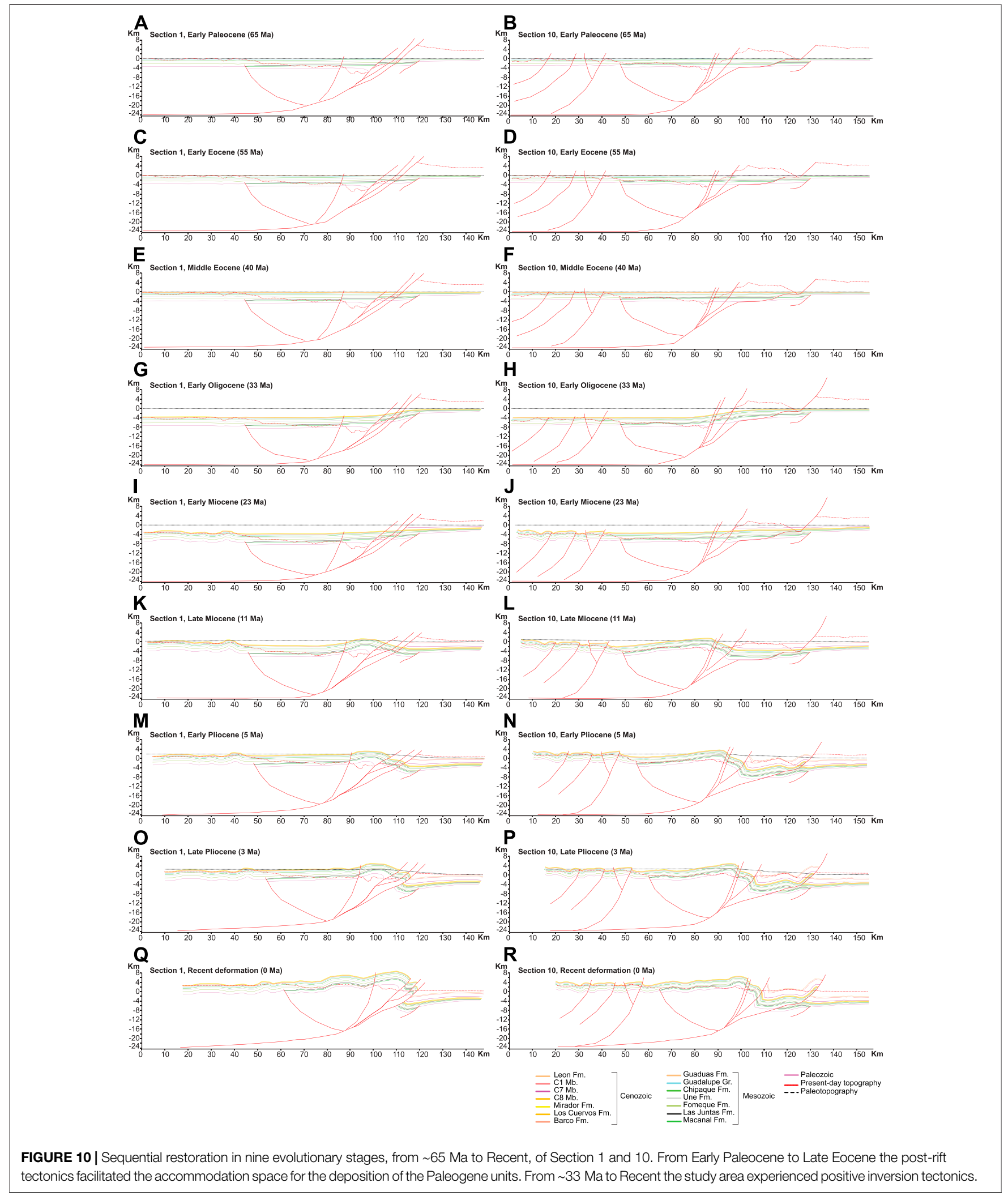

associated with the geometry of the Guaicaramo fault ramps. This fault detaches in the Lower Cretaceous shales underneath the Nazareth syncline, it ramps up to an intermediate detachment in the Upper Cretaceous units, and then it climbs up to the topographic surface (Rowan and Linares, 2000). 


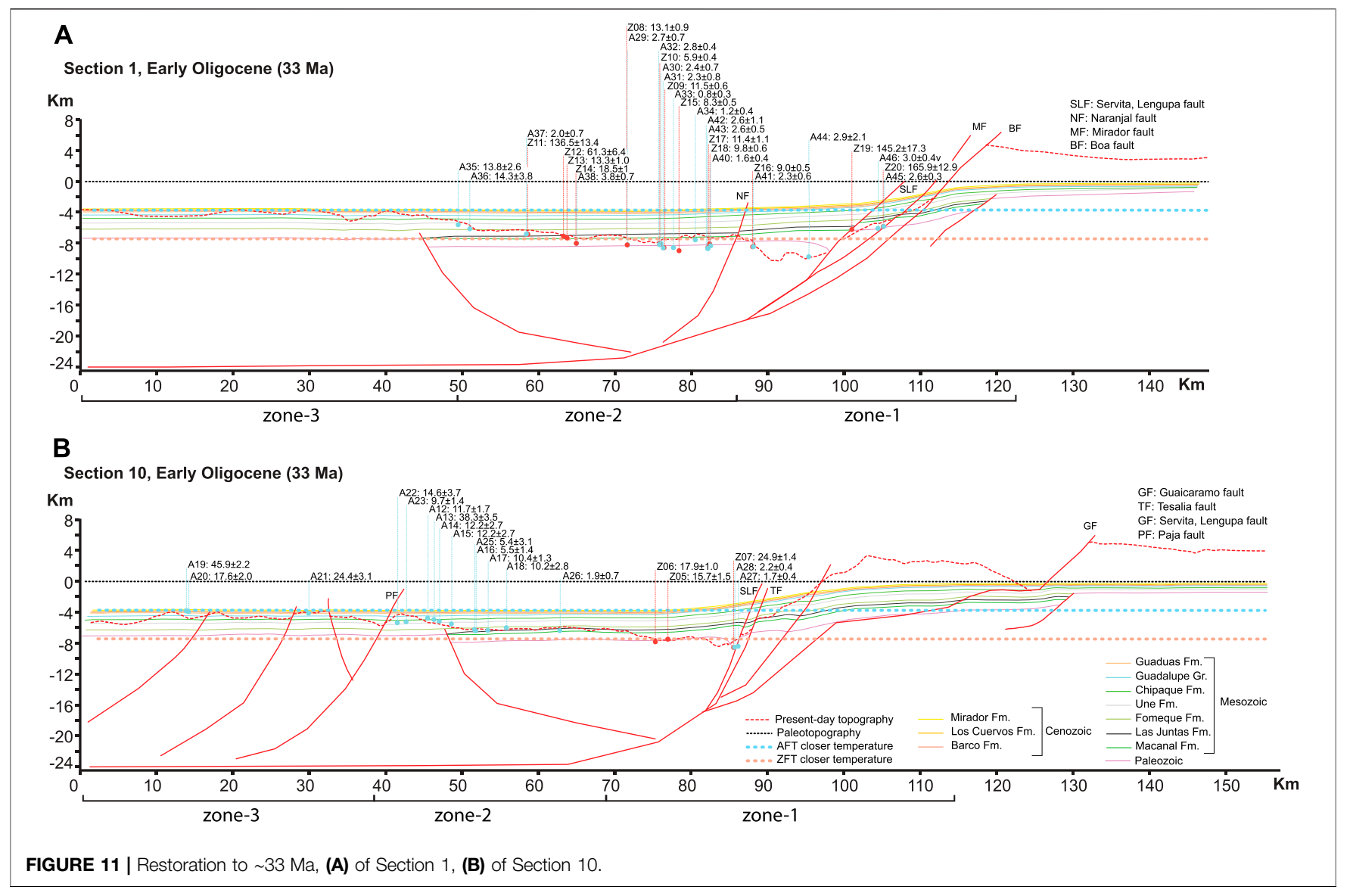

The deformation process of the inversion tectonics from the Early Oligocene to Recent on both section is described in the following.

\section{Configuration Prior to Shortening ca. $33 \mathrm{Ma}$ (Early Oligocene)}

Previous studies based on thermochronological information, stratigraphic sections, and sedimentary petrology (e.g., Horton et al., 2010; Parra et al., 2009b; Parra et al., 2010; Ramirez-Arias et al., 2012) present evidence which date the initial exhumation in the Eastern Cordillera during the Oligocene. Hence, the $33 \mathrm{Ma}$ restoration (Figure 11) is considered the youngest structural setting before the compressional tectonics; also, the maximum sedimentary load is assumed for this stage. The C8 Member (of the Carbonera Formation) in the foothill and The Llanos, and the Concentracion Formation on the Eastern Cordillera were deposited during this age (Cooper et al., 1995). The C8 Member is described as marine-influenced and lower coastalplain sedimentation (Cooper et al., 1995), therefore the paleotopography is assumed to be a flat-lying surface vertically located near the mean sea level (Figure 11).

Assuming a thermal gradient of approximately $25^{\circ}-30^{\circ} \mathrm{C}$ per kilometre in depth (Allen and Allen, 2006), the closure temperature of apatite fission tracks $\left(\sim 120^{\circ} \mathrm{C}\right)$ can be estimated with a line which is parallel to but $4 \mathrm{~km}$ underneath the paleotopography. Applying the same reasoning, the closure temperature of the zircon fission track $\left(\sim 240^{\circ} \mathrm{C}\right)$ can be estimated at $8 \mathrm{~km}$ beneath the paleotopography. This apatiteclosure-temperature approximation in all models is demarked by a light-blue dashed line and referred to as ACTA; whereas the zircon-closure-temperature approximation is referred as ZCTA, and is displayed as the light-red dashed line (Figures 11-16).

For the necessity of projecting the samples onto the sections, some thermochronometers display an offset with respect to the Present-day topography (in dashed red line in Figure 11). Additionally, some small amendments (vertical movements) were made on the projected samples to honor their relative position in relation to the formations from which they were extracted. To clarify the analysis of the thermochronological data both sections have been divided into three zones. Zone- 1 covers the Foothill and the frontal thrust system of the Eastern Cordillera (Figure 11). Zone-2 extends across the central portion of the sections, which is featured in the Present-day deformation by a marked monocline dipping northwest. Zone-3 covers the area of the Bogota Savanna. Note that Section 1 does not have thermochronometers located over zone-3, therefore the deformation and analysis of this zone are inferred from Section 10.

In zone-1 of Section 10, ZFTs Z05 and Z06, which are located in Macanal Formation (Figure 11B) display an average age of $16 \mathrm{Ma}$. They are considered reset, and this is consistent with their 


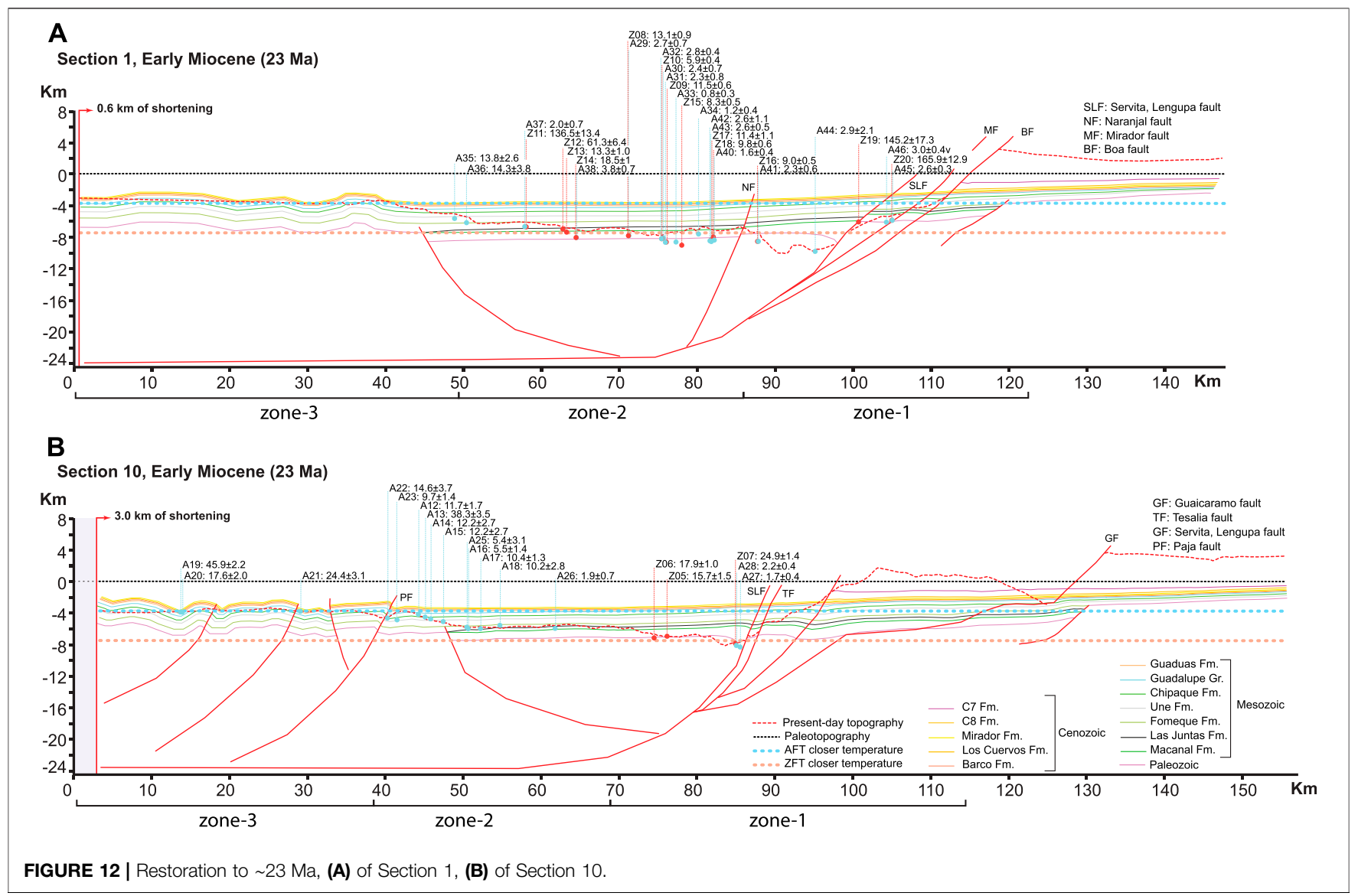

relative location with respect to the ZCTA as they are displayed beneath the light red-dashed line. A similar analysis can be applied to sample $\mathrm{Z} 07$ which is located in the Farallones Group. From the AFT samples A27 and A28, it is also inferred that the samples are reset with and average age of 2.0 Ma, and located beneath the ACTA. In zone-1 of Section 1

(Figure 11A) there are three ZFT samples, Z16 (in Quetame Group), Z19 and Z20 (both in Buenavista Fm). Z19 and Z20 display anomalous ages of 145.2 Ma and 165.9 Ma respectively. These dates markedly contrast with the overall knowledge about the structural evolution of this belt, therefore it is assumed that they have never reached the zircon closure temperature $\left(\sim 240^{\circ}\right)$. Consequently, they can be observed in Figure 11B above the ZCTA. In this zone the apatite fission track age is in an average of $2.7 \mathrm{Ma}$ with all the samples being reset (A41, A44, A46, A45).

Zone- 2 of Section 10 (Figure 11B) is populated by eleven AFT samples. Every sample appeared to be reset, apart from A13 which displays an anomalous apatite age of $38 \mathrm{Ma}$, indicating that it could be partially annealed. To the southeast portion of this zone samples A16 to A18, A25, and 26 are located in the Early Cretaceous formations and they have an average apatite age of 6.7 Ma. To the northwest part of this zone, samples A12, A14, A15, A22, and A23 are located in the post-rift (Late-Cretaceous) formations with an average apatite age of $8.4 \mathrm{Ma}$. In zone-2
Section 1 (Figure 11A), the fission track samples were collected from the deepest stratigraphic units exposed on the Present-day topographic surface (from the pre Devonian Quetame Group to the Early Cretaceous formations). In the southeast portion of this zone the ZFT samples Z8 to Z10, Z15, Z17 and Z18 appear to be reset, with an average zircon age of $10.0 \mathrm{Ma}$. The average apatite age calculated from A29 to A34, A40, A42, and A43 in this area is $2.1 \mathrm{Ma}$. In the northwest portion of this zone two zircon fission track samples Z11 (136.5 Ma), and Z12 (61.3 Ma) appear not to be reset, therefore in the pre-deformation model they are located above the ZCTA. The apatite fission track samples A35 to A37, placed in the Lower Cretaceous formations to the northwest of this zone, have an average apatite age of 10.0 Ma.

In zone- 3 of Section 10 (Figure 11B) there are three AFT samples, A19 to A21. A19 is from the Paleogene Upper Socha Formation, having an apatite age of $45 \mathrm{Ma}$, which indicates that it could be partially annealed. A20 (17.6 Ma) and A21 (24.4 Ma), which are consider reset, are located in the Paleocene Cacho Formation and Late Cretaceous Guadalupe Group respectively.

\section{Restoration ca. $23 \mathrm{Ma}$}

At the beginning of the Miocene age ( 23 Ma) the C5 Member (of the Carbonera Formation) was deposited on the foreland basin (Figure 12). The inferred paleoelevation analysis (Figure 6) indicates that before the Middle Miocene $(\sim 15 \mathrm{Ma})$ the 


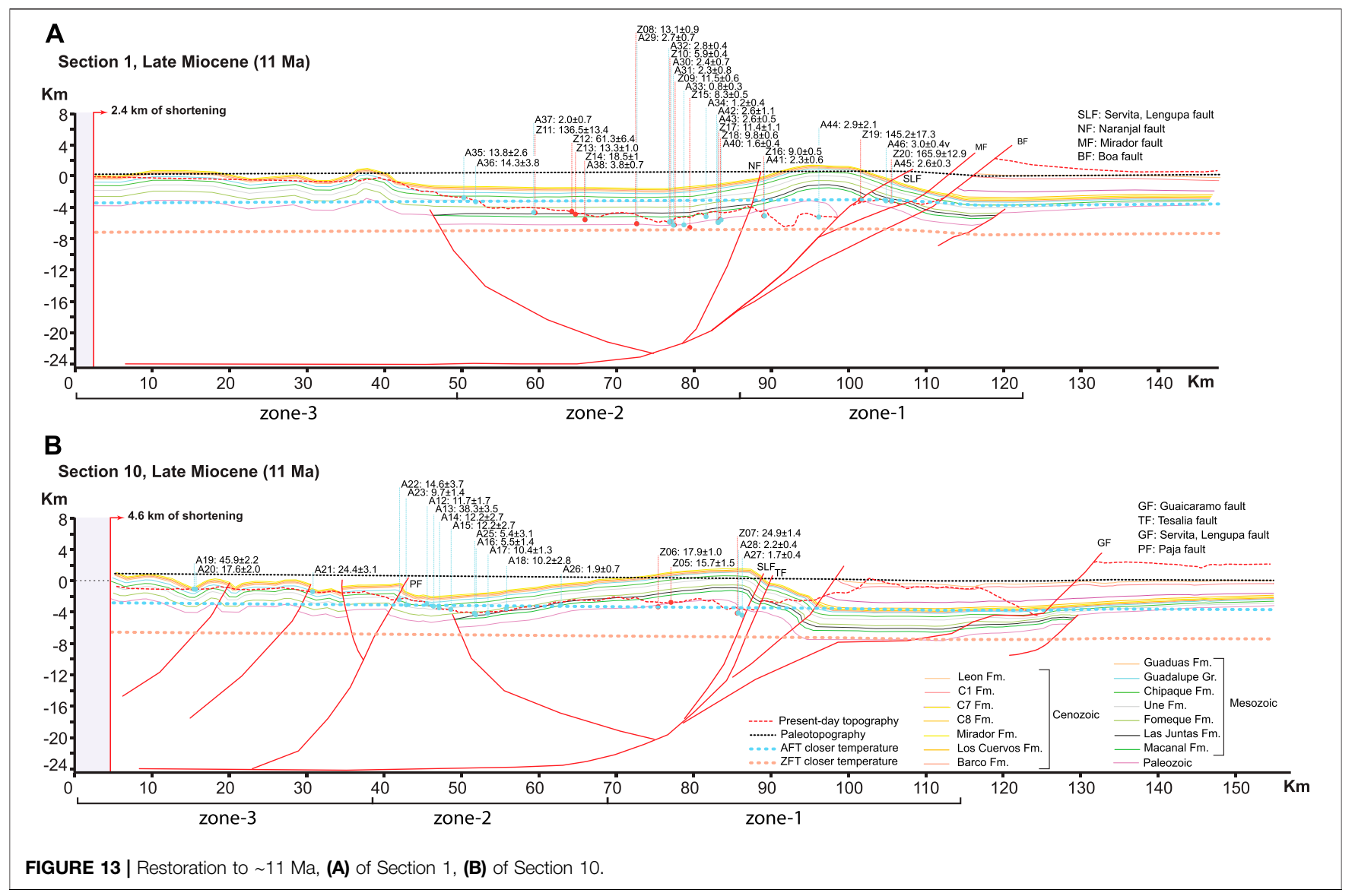

paleotopography was similar to the mean sea level in the region. This is consistent with the marine influenced origin of C5 Member (Cooper et al., 1995).

The deformation initiated during the Middle Eocene to Oligocene (Parra et al., 2009b; Horton et al., 2010; Parra et al., 2010; Ramirez-Arias et al., 2012) along the axial zone. After the initiation, the western portion strain has propagated toward the Magdalena Valley, whereas the eastern portion toward The Llanos in an overall symmetric fashion (Figure 2). The eastward deformation is reflected in this model with the initial deformation localized in zone-3 (Figure 12). It is in zone-3 of Section 10 that the AFT samples with oldest apatite ages are extracted. The reset samples in this zone (A20 and A21) have an average apatite age of $20 \mathrm{Ma}$, therefore during this period they should be located near the ACTA - $4 \mathrm{~km}$ in depth (Figure 12B). The deformation in this zone, but in Section 1 (Figure 12A), has been inferred by taking into account the lateral continuity from Section 10 toward the south. The accumulative shortenings from $\sim 33 \mathrm{Ma}$ to $\sim 23 \mathrm{Ma}$, are 0.6 and $3.0 \mathrm{~km}$ for Section 1 and 10, respectively.

It has been mentioned above, that the onset of deformation estimated in the literature for the western structural domains (Saylor et al., 2012a; Saylor et al., 2012b), which is the zone-3, occurred by the Late Eocene. Therefore, the deformed section at $23 \mathrm{Ma}$ actually represents the finite shortening that occurred between the Late Eocene and Late Oligocene. In this context, the available apatite ages give a minimum age for the exhumation and associated shortening.

\section{Restoration to ca. $11 \mathrm{Ma}$}

At the Late Miocene ( 11 Ma) the Leon Formation was deposited in the study area (Figure 13). An interpolation of the paleoelevation information (Figure 6) has been used to model the paleotopography. At the hinterland the elevation is assumed to be approximately $1000 \mathrm{~m}$, progressively decreasing toward The Llanos until reaching similar values to the mean sea level.

During the period between $\sim 23 \mathrm{Ma}$ and $11 \mathrm{Ma}$, in zone- 3 on both sections, the exhumation continued with the AFT samples in a cooler position above the ACTA. The deformation propagated toward zone-2 and northwest of zone-1. The structural evolution from $\sim 23 \mathrm{Ma}$ to $\sim 11 \mathrm{Ma}$ is featured in the inversion of the ServitaLengupa fault system forming a gentle and long-wave anticline (Figure 13). This anticline is asymmetric in Section 10 with a lengthy back limb dipping toward the northwest; whereas in Section 1 it appears to be symmetric (Figure 13).

Every ZFT sample located along Section 10 was in a cooler position with respect to the ZCTA (Figure 13B). In Section 1, at the southeast part of zone-2, ZFT samples (Z08 to Z10, Z15 to $\mathrm{Z18}$ ) with an average zircon age of $9.9 \mathrm{Ma}$ were distributed near the ZCTA (Figure 13A). This constrains the anticline symmetry since it generates a steeper and shorter backlimb compared to the anticline geometry observed on Section 10 . To the northwest part 


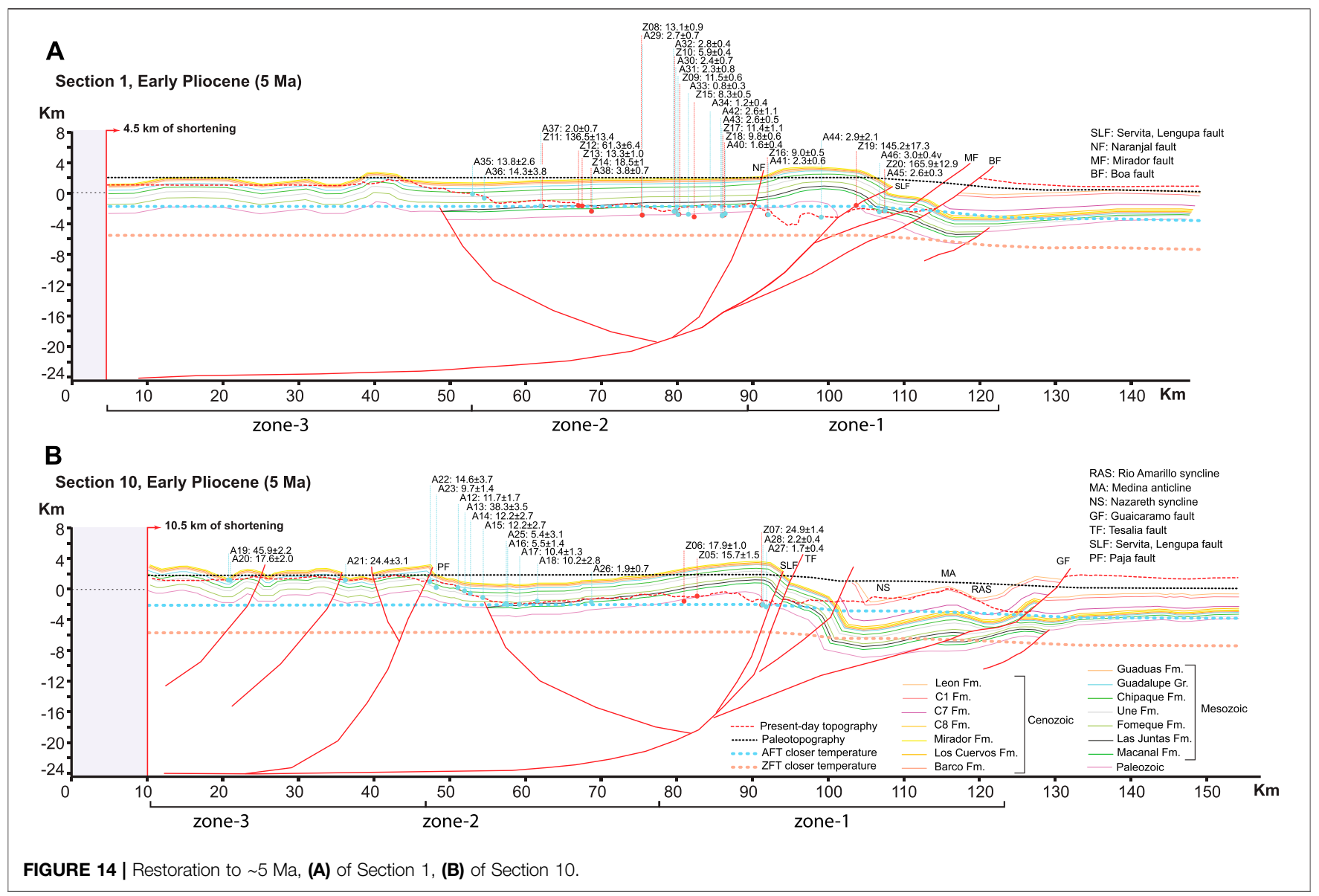

of zone-2 the reset ZFT samples (Z13 and Z14) with older zircon ages were located in a cooler position with respect to the ZCTA. The AFT information indicates that, in both sections, the AFT samples collected on the Present-day topography at this stage were located near the ACTA.

The frontal system uplift, in both sections, was bounded by the moderate to steep extensional faults of the Servita, Lengupa, and Tesalia complex. However, in this initial stage of the frontalsystem development, the fault offsets are not interpreted with inversion. The topographic load caused by the frontal-system initial uplift resulted in a flexural response which initiated a foreland basin (foredeep depozones, cf. Parra et al., 2009a). The development of the foreland basin accommodated the stemmed sediments proceeding primarily from the frontal-uplift erosion. The gravel-clast petrography analysis (Figure 7) presented by Parra et al. (2010) suggests that from the Middle Oligocene to $\sim 11 \mathrm{Ma}$, the sediments in this foreland basin came from the erosion of the Paleocene-Eocene rocks deposited in the frontal system (Barco, Los Cuervos, and Mirador Formations). Therefore, as it is represented in this model (Figure 13), the erosion window on the frontal system exposed Upper Cretaceous rocks (Guadalupe, and Chipaque Formations). This unroofing sequence and the acceptable paleoelevations for the interval between $\sim 23 \mathrm{Ma}$ and $\sim 11 \mathrm{Ma}$ are the most precise constraints to reconstruct the actively deforming areas for that time. The accumulative shortenings from $\sim 33 \mathrm{Ma}$ to $\sim 11 \mathrm{Ma}$, are 2.4 and $4.6 \mathrm{~km}$ for Section 1 and 10, respectively (Figure 13).

\section{Restoration ca. $5 \mathrm{Ma}$}

The Early Pliocene marked a depositional transition from the Lower to Upper Guayabo Formation (Figure 14). The paleotopographic reconstruction for this model step is interpreted (for both sections) with an altitude of $2000 \mathrm{~m}$ in the hinterland (Wijninga, 1996; Hooghiemstra et al., 2006), which progressively decreases toward the southeast to the mean sea level in The Llanos. Different published regional interpretations inside, and nearby the study area, support the hypothesis that the deformation rates were much faster during the last $5 \mathrm{Ma}$ (e.g., Martinez, 2006; Mora A. S. et al., 2013; Mora et al., 2014). In the study area Mora et al. (2008) show very young AFT ages $(<3 \mathrm{Ma})$ on top of a frontal basement thrust that imply acceleration of exhumation and shortening rates. To the north and along the eastern foothills cross-cutting relationships in well constrained cross-sections interpreted by Tamara et al. (2015) show that the longest traces (in profile view) of the most frontal faults cut through Late Miocene-Pliocene sedimentary units.

The analysis of the AFT samples indicates that in Section 10 the apatite ages decrease from northwest to southeast. In zone-3 and northwest part of zone- 2 the apatite samples are older than $5 \mathrm{Ma}$; consequently, in our model they are located above the ACTA. From the middle of zone-2 toward The Llanos the 


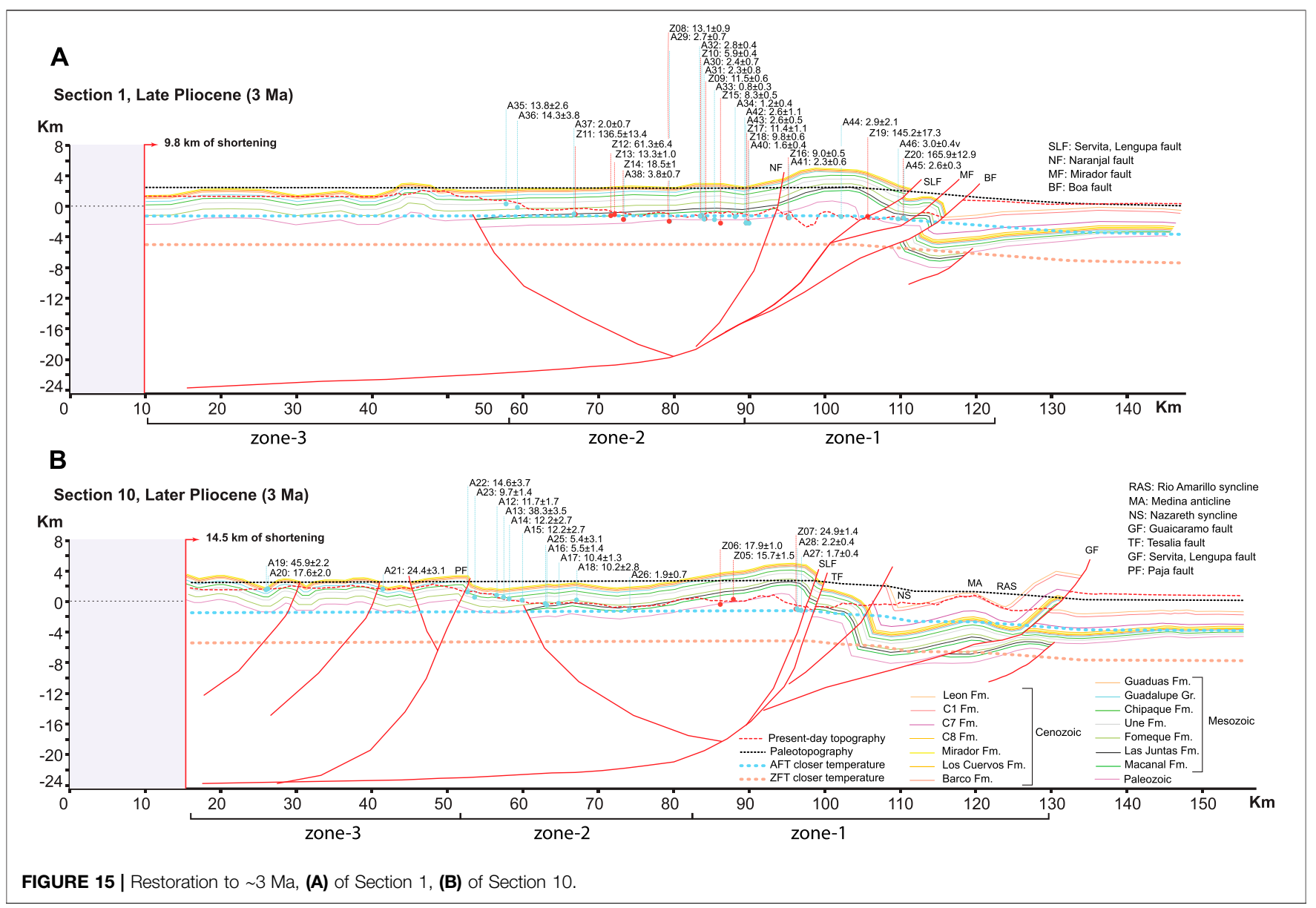

samples have younger ages; therefore they are located nearby the AFTA, or even below. A similar situation is observed in Section 1 in which, apart from A35 and A36, the apatite ages from mid zone-2 toward The Llanos are younger than $5 \mathrm{Ma}$.

From $11 \mathrm{Ma}$ to this stage the compressional deformation continued its overall forward propagation. This caused: 1) the inversion of the master extensional faults underling the frontal system (Servita-Lengupa fault), and 2) the initiation of a series of low-angle shortcut faults, which resulted in a thin-skinned system (Boa and Guaicaramo faults). Following the early period of folding in the frontal system, in this stage the continuous shortening initiated the fault inversion of the principal extensional faults. In Section 10 (Figure 14B), the inversion offsets for the Servita-Lengupa and Tesalia faults were $220 \mathrm{~m}$ and $380 \mathrm{~m}$, respectively. In Section 1 (Figure 14A), the ServitaLengupa fault displacement was $950 \mathrm{~m}$. Note that the Naranjal fault, in Section 1, has remained extensional during the entire fold-and-thrust belt formation (see frontal system in Figure 14A). A series of low angle shortcut faults broke through the stratigraphic section. They are located between the inversion faults and the foreland basin trough with an angle of approximately $30^{\circ}$. The seismic profiles display the low angle of the shortcut faults from the Cretaceous units to younger; however, the seismic coverage and resolution preclude a confident fault interpretation in deeper units. Therefore, these faults are tentatively interpreted here as connected to the inversion faults (cf. Rowan and Linares, 2000; Mora and Parra, 2008; Tesón et al., 2013). In Section 1, the Boa fault had $450 \mathrm{~m}$ of displacement, whereas the Mirador fault continued being inactive. In Section 10, a low displacement shortcut fault is interpreted at the side of the foreland basin trough; however, the most significant characteristic of zone- 1 is the occurrence of the Guaicaramo fault (Figure 14B). The Guaicaramo fault is a multi-ramp thrust fault formed by two low-angle ramps $\left(\sim 30^{\circ}\right)$ and a sub-horizontal segment in between, which is located in the Upper Cretaceous section. The movement of the hanging wall over the fault ramps resulted in a fault-bend fold-the Medina anticline. In this early evolutionary stage the Medina anticline (also known as Guavio anticline) displays a large wavelength and low amplitude, flanked by the Nazareth syncline to the hinterland, and the Rio Amarillo syncline to the foreland.

The gravel-clast petrography analysis (Figure 7) indicates that the erosion of the upper and middle section of the Une Formation was the main source of sediments in the foreland basin during this period (Parra et al., 2010). These sediments are thought to come from the uplift of the frontal system, and that fact is reflected in this evolutionary model with an erosion window exposing the lower units of the Une Formation in the proximities of the inversion faults (Figure 14). The accumulative shortenings 


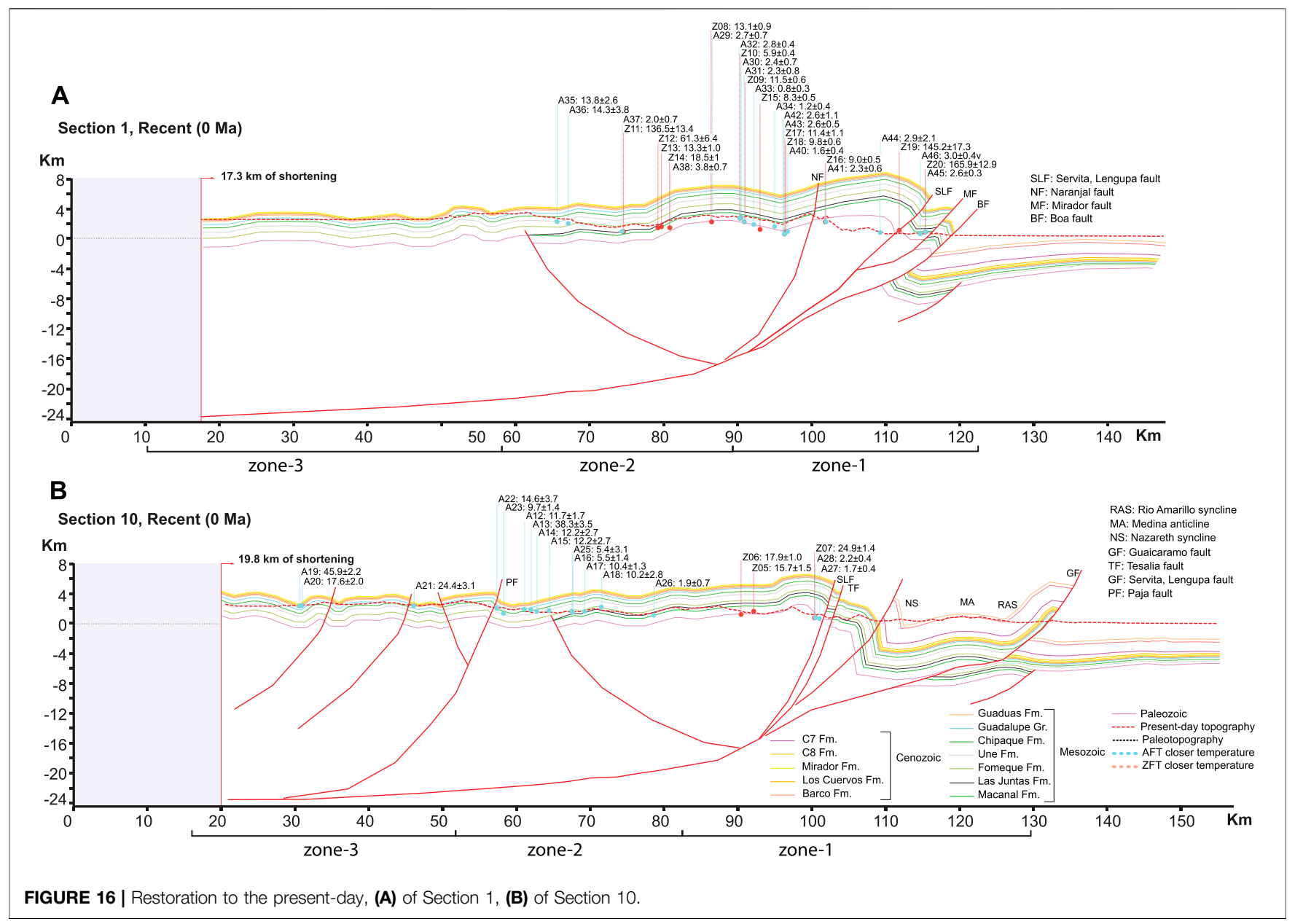

from $\sim 33 \mathrm{Ma}$ to $\sim 5 \mathrm{Ma}$, are 4.5 and $10.5 \mathrm{~km}$ for Section 1 and 10, respectively (Figure 14).

\section{Restoration ca. 3 Ma}

From $5 \mathrm{Ma}$ to the Late Pliocene the upper Guayabo Formation was depositing in the foreland basin (Figure 15). In this stage the paleotopography (Figure 6) was comparable to the Present-day elevation; with approximately $2500 \mathrm{~m}$ above the mean sea level in the hinterland and near the mean sea level in The Llanos (Wijninga, 1996; Hooghiemstra et al., 2006).

In Section 10 (Figure 15B), AFT samples A28 and A27 which are located in zone-1 (in the hanging wall of the inversion fault system), and A26 located in zone-2 (in the back limb of the frontal system) are younger than this period. Therefore they are located near the ACTA. Likewise, in Section 1 the AFT samples distributed from the end of the frontal-system back limb (in zone-2) to the middle of zone-1 are younger than this stage.

In Section 1 (Figure 15A) the Servita-Lengupa inversion fault had 1450 m of displacement; whereas in Section 10 the ServitaLengupa and Tesalia faults had 450 and $750 \mathrm{~m}$, respectively. In this stage the structural activity in both sections was mostly focused in the development of the shortcut-fault system. In Section 1, the Boa fault had $4000 \mathrm{~m}$ of total displacement, while Mirador fault is interpreted inactive. In Section 10, the Guaicaramo fault had $6100 \mathrm{~m}$ of displacement and the overlying hanging wall continued its deformation increasing the Medina anticline amplitude.

The sediments deposited from $5 \mathrm{Ma}$ to this stage came from the lower sections of Une Formation according to the gravel-clast petrography analysis (Figure 7). Therefore, the erosion window of this model exposes the Las Juntas Formation in the frontal system. The accumulative shortenings from $\sim 33 \mathrm{Ma}$ to $\sim 3 \mathrm{Ma}$, are 9.8 and $14.5 \mathrm{~km}$ for Section 1 and 10, respectively (Figure 15).

\section{Present-Day Structural Context 0 Ma}

At present, the topographic elevation in the northwest portion of both sections (in zone-3) is approximately $2800 \mathrm{~m}$ (Figure 16), however from the Pajarito fault toward the southeast it decreases progressively until The Llanos - where it reaches few hundred of meters above the mean sea level $(\sim 200 \mathrm{~m})$.

During this last deformation stage, the deformation was mainly distributed along zone-1 and 2 in both sections. Folding is the dominant structural style in zone-2; whereas in zone-1 the shortcut thrusts experienced large fault slip. In Section 10 (Figure 16B), the Guaicaramo fault accommodated $9200 \mathrm{~m}$ of total shortening; whereas in Section 1 the Boa and Mirador 
faults accommodated $8000 \mathrm{~m}$ and $1900 \mathrm{~m}$, respectively (Figure 16A).

All the AFT samples which were located near the ACTA in zone- 1 and 2 in the previous stage are at the present on the topographic surface. This indicates that during this period zone-2 and 1 underwent a rapid exhumation (approximately $4 \mathrm{~km}$ of exhumation in $3 \mathrm{Myr}$ ). This rapid exhumation is quantified and discussed below in the context of the entire deformation.

\section{DISCUSSION}

The reconstruction models highlight two marked tectonic periods: 1) post-rift subsidence during the Early and Mid Paleogene (Figures 10A-H), and 2) positive inversion from the Oligocene to Recent (Figures 10H-R). This research emphasizes in the Oligocene to Recent contraction, which has resulted in the aforementioned tectonic inversion of this orogen.

The reconstruction models (Figures 11-16) indicate that the overall compressive deformation initiated during the Oligocene (from $\sim 33$ to $\sim 23 \mathrm{Ma}$ ) in the hinterland (Bogota Savanna) and propagated southeastward to The Llanos. The quantitative analysis (below discussed) shows an overall constant shortening ratio of $200 \mathrm{~m} / \mathrm{Myr}$ (meters per million years) from the Oligocene to Early Pliocene, which rapidly increases to approximately $2500 \mathrm{~m} / \mathrm{Myr}$ from the Early Pliocene to Recent. A significant regional uplift is observed in the Bogota Savanna from the Oligovene to Early Pliocene compared to the low shortening ratio ( $200 \mathrm{~m} / \mathrm{Myr})$ during this period. This issue is discussed in further details below, as well as the non-uniqueness of this model and the structural analysis.

\section{Non-uniqueness of the Balanced Palinspastic Restoration}

Line-length balanced palinspastic restoration is a valuable tool to understand the structural evolution of a deformed geological setting; however, it offers a non-unique solution. Although the synoptic view is reasonably well constrained by the involved geological elements; any one part of the reconstructed geology may be depicted with limitations. For example, the precise structural style of individual structures cannot be established with complete certainty. In this research the kinematic evolution of the anticlines is assumed to be similar to a breakthrough (or break-thrust) anticline (cf. Willis and Willis, 1934), such is the case for the Farallones anticline in the frontal system. In this anticline an initial period of basement-involved folding from $\sim 23 \mathrm{Ma}$ to $\sim 5 \mathrm{Ma}$ is assumed before the extensional-fault inversion.

It has been debated whether the frontal basement uplift and antiform, the Farallones anticline, is a huge basement involved fold or an antiform whose structural relief is caused by basement duplexes (see discussion in McClay et al., 2018). The deep erosion inside the river canyons like the Guayuriba river (Mora et al., 2006) allowed to document that the basement is actually folded into a huge anticline without the presence of basement duplexes. This favors the lesser shortening solution proposed by McClay et al. (2018), which requires a distribution of less amounts of basement shortening through time.

The 2D model presented here is first order at best. It has been achieved by line-length balancing; however the internal deformation and volume loss that a thrust sheet experiences before starting to move along a discrete fault plane, in many cases, can be considerable (e.g., Williams et al., 1989). Different authors investigated the causes of volume and material loss in the crustal thicknesses of the Andes Cordillera (e.g., Mora A. et al., 2013; Eichelberger et al., 2015; Kammer et al., 2020). Eichelberger et al. (2015) ran two models using map-view reconstruction of the Andes in Bolivia to predict the crustal thicknesses of the central Andres. These models predicted volumetric excess of $8 \%$ and $25 \%$. Eichelberger et al. (2015) argue that the volume excess in this region can be accounted for by "lower crustal flow" and/or "removal of lower crust" during the Andean deformation. Furthermore, fluid inclusions and outcrop-based structural analysis conducted in the study area (Mora A. et al., 2013) denoted that second-order folding associated to internal strain occurred prior to the first-order deformation. Kammer et al. (2020) and Mora A. et al. (2013) document that total amounts of basement shortening by ductile deformation could represent $30 \%$ of the total shortening estimates. Additionally, Mora A. et al. (2013) suggest that most basement folding occurred when those rocks were at depths higher than $7 \mathrm{~km}$, favoring a ductile behavior of the basement. The low shortening rates from Paleogene and Early Neogene documented in this work also could be associated with this ductile deformation. However, in this research, we do not consider additional ductile or internal strain for the shortening estimates.

To constrain the kinematic evolution with thermochronometry, a constant thermal gradient of approximately $25^{\circ}-30^{\circ} \mathrm{C}$ per kilometer in depth was assumed. This allowed for the calculation of the apatite and zircon closuretemperature approximations (ACTA and ZCTA, respectively), which are parallel to the paleotopography and located approximately 4 and $8 \mathrm{~km}$ beneath, respectively. However, the ACTA and ZCTA are just simplifying assumptions. The prediction of the thermochronometric ages in tectonically active settings depends on factors such as: erosion history, topographic relief, thermophysical properties of the rock, and fault kinematics and geometry. When thrust faults propagate upward along footwall ramps, the vertical component of motion and the exhumation advect heat upward. Then, whether this topographic relief is rapidly eroded, the upward advection of isotherms is enhanced. Contrarily, the sediments deposited in the foreland basin are subsequently buried to exert a downward advection of the isotherms. Therefore, assuming closure temperatures only depending on the topographic level represent a limitation of our method. Furthermore, the subsurface thermal field that is affected beneath the individual structures by both surface uplift via faulting, and erosion focused over active uplift was documented in numerous works (e.g., Ter Voorde et al., 2004; Huerta and Rodgers, 2006; Lock and Willett, 2008; McQuarrie and Ehlers, 2017). Greater accuracy of the thermal field can be obtained by means of software packages like Pecube (Braun, 2003; Whipp et al., 2009; McQuarrie and 
Ehlers, 2015), and Fetkin (Almendral et al., 2015; Mora et al., 2015a). Even taking all these factors into account, this evolutionary model satisfies the current known constraints of the first order structural geometry, pressure-temperature time constraint, stratigraphy, and basic shortening estimations.

\section{Paleoelevation Data: Lipid Biomarkers Versus Paleobotanic Assessments}

The scopes and challenges of using paleobotanic data to relate topographic elevations with geological ages are discussed here. As it is mentioned above, Hooghiemstra et al. (2006), and Wijninga (1996) used the nearest living-relatives-paleobotanic method to assess past elevations in the Eastern Cordillera. Different authors (e.g., Molnar and England, 1990) suggest that this is a risky method of assessing paleobotanic data, since certain species which today live at specific elevations may not have lived at the same elevations in previous times. However, Hooghiemstra et al. (2006), and Wijninga (1996) have compiled years of studies regarding the vegetation history of the Eastern Cordillera; therefore, it is difficult to debate about this knowledge without evidence that rejects the way of interpreting their data. Generally, the risk exists for the nearest-living-relatives method, but Hooghiemstra et al. (2006), and Wijninga (1996) use populations of species.

In our view, the main uncertainty of this method is not precisely that one. Instead, the risk may be to assign to the biozones from Hooghiemstra et al. (2006), and Wijninga (1996) a higher accuracy than the actual one. Perhaps this is one of the misinterpretations in Mora et al. (2008), where the authors proposed that the data from Hooghiemstra et al. (2006), and Wijninga (1996) suggests a topographic growth between 6 and $3 \mathrm{Ma}$. Certainly, Figure 6, modified from the original one by Hooghiemstra et al. (2006), and Wijninga (1996), and reproduced by Mora et al. (2008), does not precisely shows a topographic growth between 6 and $3 \mathrm{Ma}$, but a wider range from Mid Miocene to Pliocene.

More recently, Anderson et al. (2015) provided more accurate review about the previous hypothesis by Hooghiemstra et al. (2006), and Wijninga (1996). In fact the refined $\sim 8 \mathrm{Ma}$ age for the base of the Salto de Tequendama I and II sections by Anderson et al. (2015) is coincident with the initial assessments of Mid Miocene to Pliocene by Hooghiemstra et al. (2006), and Wijninga (1996). This is also the case of the paleotemperature estimates. Hooghiemstra et al. (2006), and Wijninga (1996) do not provide a paleotemperature estimate but actually a paleoelevation range, which is broad for the Subachoque 39 and Salto del Tequendama I and II sections (Figure 6). In such case, we can emphasize that both data sets do not disagree.

\section{Structural Analysis and Evolution}

Accumulative shortening from $33 \mathrm{Ma}$ to Recent was calculated on both sections (Table 2 and Figure 17A). The shortening curves display a subparallel trend. Section 10 underwent approximately $2 \mathrm{~km}$ more shortening from the compression onset to Recent. Along the time, the shortening was increasing in the study area on both sections, but not constantly. From the analysis of the average accumulative-shortening curve (Figure 17A) three marked tendencies were observed. First, from $\sim 33 \mathrm{Ma}$ to $\sim 11 \mathrm{Ma}$, when the study area deformed with a relatively low and constant shortening rate of $\sim 160 \mathrm{~m} / \mathrm{Myr}$; experiencing an average of $\sim 3.5 \mathrm{~km}$ of accumulative shortening. Second, from $\sim 11 \mathrm{Ma}$ to $\sim 5 \mathrm{Ma}$, when the rate increased to $\sim 650 \mathrm{~m} / \mathrm{Myr}$, resulting in an accumulative shortening of $\sim 7.5 \mathrm{~km}$. Finally, from $\sim 5 \mathrm{Ma}$ to Recent, when the deformation has experienced a significant acceleration that raised the rate at $\sim 2200 \mathrm{~m} / \mathrm{Myr}$. The total accumulated shortening at the present is $17.3 \mathrm{~km}$ and $19.5 \mathrm{~km}$ on Section 1 and Section 10, respectively. This results in an average of shortening rate of $\sim 550 \mathrm{~m} / \mathrm{Myr}$ from $\sim 33 \mathrm{Ma}$ to Recent.

The above described accumulative shortening was not homogeneously accommodated along the study area. Hence, to understand the propagation sequence of the deformation, as well as the strain distribution, shortening rates have been calculated for the three principal structural domains of Section 10 (Figure 17B). These shortening rates were calculated dividing the shortening by the time frame. The following analysis is also well representative of the deformation in Section 1. The "Bogota Savanna" is one of these domains, and it covers the most northwest part of the study area to the Paja fault (Figure 9). The "Frontal System" domain is bounded by the Paja fault to the northwest and the Tesalia fault system to the southeast. "Medina Basin" domain is flanked by Tesalia fault system to the northwest and extends to The Llanos basin.

From the beginning of the compressional deformation, approximately from $33 \mathrm{Ma}$ to $23 \mathrm{Ma}$, the shortening was accommodated along the Bogota-Savanna domain. During that period, the rate of shortening was $\sim 260 \mathrm{~m} / \mathrm{Myr}$ yielding $\sim 3 \mathrm{~km}$ of shortening (Table 3). In this period, the Frontal System and Medina Basin remained inactive. From $\sim 23 \mathrm{Ma}$ to $\sim 11 \mathrm{Ma}$ the structural activity was constrained in the Frontal System with a shortening rate of $\sim 83 \mathrm{~m} / \mathrm{Myr}$ that resulted in $\sim 1 \mathrm{~km}$ of shortening; whereas the other two domains were inactive (Figure 17B). From $\sim 11 \mathrm{Ma}$ to $\sim 5 \mathrm{Ma}$ the Medina Basin, which had been inactive before, rapidly started deforming with a rate of $\sim 1000 \mathrm{~m} / \mathrm{Myr}$. From $\sim 5 \mathrm{Ma}$ to $\sim 3 \mathrm{Ma}$ two domains synchronically deformed, since Medina Basin increased its shortening rate to $\sim 1750 \mathrm{~m} / \mathrm{Myr}$, and the Frontal System was reactivated with a rate of $\sim 250 \mathrm{~m} / \mathrm{Myr}$. From $\sim 3 \mathrm{Ma}$ to Recent these two domains have remained active with rates of $\sim 1500 \mathrm{~m} /$ Myr and $\sim 333 \mathrm{~m} / \mathrm{Myr}$ for the Medina Basin and the Frontal System, respectively. The accumulative shortening in the Medina Basin from $\sim 11 \mathrm{Ma}$ to Recent has been $14 \mathrm{~km}$. The shortening accumulated in the Frontal System in its last reactivation (from $\sim 5 \mathrm{Ma}$ to Recent) has been $\sim 2 \mathrm{~km}$.

The shortening rates differentiated by structural domains clearly display an overall forward-propagation sequence of deformation in the Eastern Cordillera and Foothill. From the shortening onset $(\sim 33 \mathrm{Ma})$ to $\sim 11 \mathrm{Ma}$ the relatively low shortening velocities, which affected the Bogota Savanna and the Frontal System domain, are associated with the thick-skinned inversion tectonics that involved basement uplift. The structural activity from $\sim 11 \mathrm{Ma}$ to Recent features an acceleration of the deformation. This shortening has been primarily accommodated 

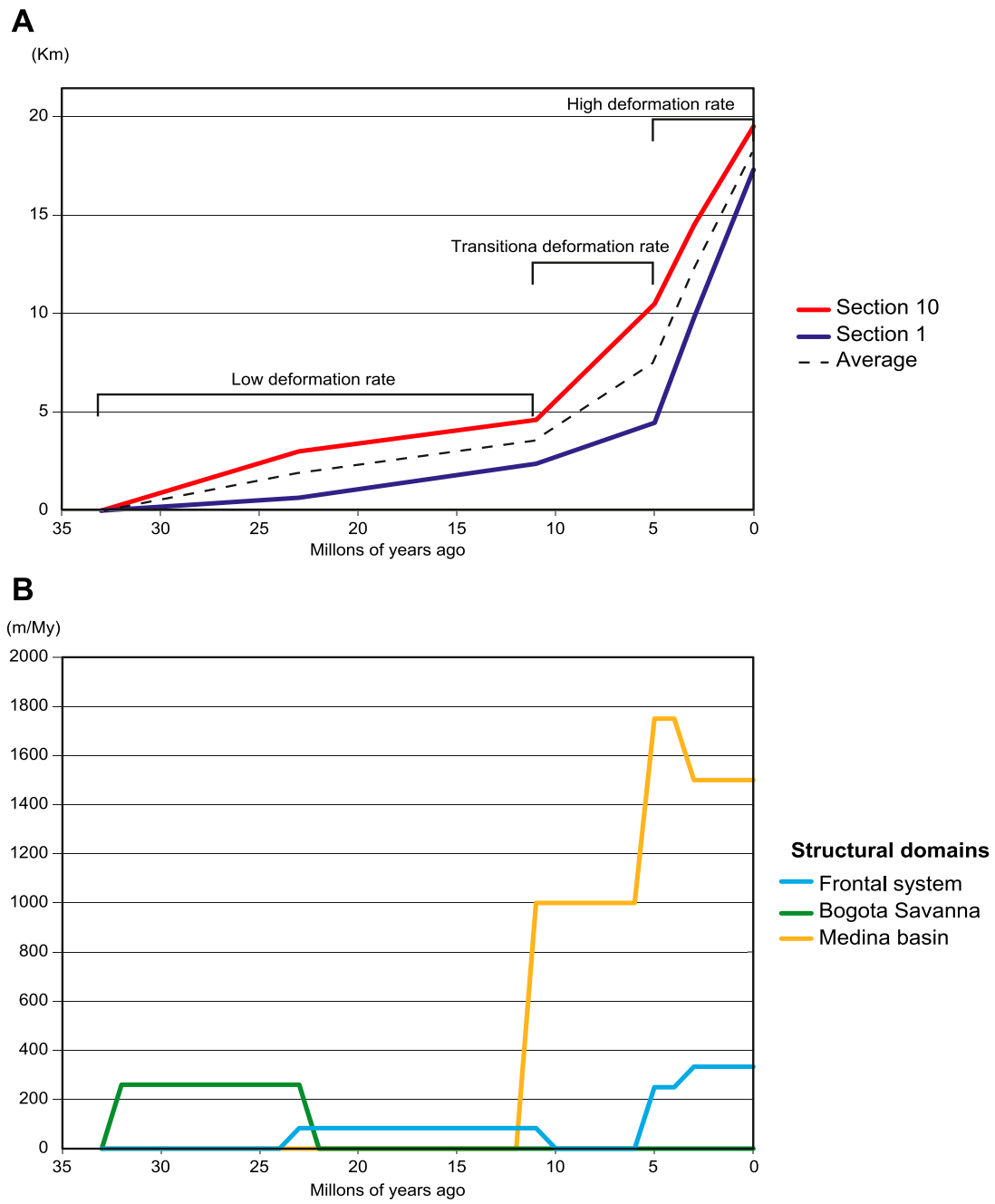

FIGURE 17 | Deformation analysis in the study area. (A) Accumulative shortening for both sections. (B) Shortening rates in different structural domains of Section 10.

TABLE 3 | Shortening rates of different structural domains of Section 10.

Geological period (Ma)

33 to 23

23 to 11

11 to 5

5 to 3

3 to 0
Bogota savanna (m/Myr)

260
0
0
0
0

Frontal system (m/Myr)

$\begin{array}{cc}0 & 0 \\ 83 & 0 \\ 0 & 1000 \\ 250 & 1750 \\ 33 & 1500\end{array}$

in the thin-skinned system of the Medina Basin, and to a lesser degree in a reactivation of the Servita-Lengupa fault in the Frontal System.

Parra et al. (2009a), based on a palinspastic restoration of Mora et al. (2008), calculated deformation rates in the Eastern Cordillera. Like this research, they suggest the occurrence of slow and rapid (i.e., unsteadily) advance of the orogenic deformation front. Additionally, the information related to the 'orogenic migration rates' presented in Table 3 by Parra et al. (2009a) suggests that the shortening rates are in the same order of magnitude as the ones established here.

\section{Comparison With Other 2D Palinspastic Restorations in Nearby Areas}

There are two recent studies related to palinspastic restorations constrained by thermochronology near the study area: Carrillo et al. (2016) and Mora et al. (2015b). The fundamental difference 
between the previous works and this investigation is that here the emphasis is on the analysis of the structural evolution, and the spatiotemporal deformation of different structural blocks; whereas the previous works focused on the refinement of the thermokinematic restorations, thermal-model validation, and testing of new technologies (Fetkin platform).

Carrillo et al. (2016) restored $302 \mathrm{D}$ balanced cross-sections from Niscota (to the northeast) to Cusiana (to the southwest) located between latitude $6.30^{\circ} \mathrm{N}$ and $4.70^{\circ} \mathrm{N}$, and longitude $73.80^{\circ} \mathrm{W}$ and $72.10^{\circ} \mathrm{W}$. They used similar geological elements to construct the cross-sections, and because their study area is in the north, this research can be considered a continuation of that investigation. They analyzed the velocity-vector variations along geological time to understand the exhumation and thermal evolution of that area. This research presents quantitative analysis of shortening velocities and rates, which can be used to validate the Carrillo et al. (2016) hypothesis.

Mora et al. (2015b), used a 2D structural section to test the capability of a new technology - Fetkin. This software gives the possibility to calibrate a kinematic restoration through the comparison between the thermal model derived from the section restoration, and the thermochronometric data collected from the field. They interpreted a larger crosssection which covers the entire Eastern Cordillera along dip direction, located south of Section 1. The thermal, exhumation, and structural evolution presented in the eastern flank of their cross-section display an overall similarity to the results of this research. They also calculated shortening rates for a number of geological periods (see Table 6 in Mora et al., 2015a) and are on the same order of the ones presented here. Note that those shortening rates were calculated in a longer cross-section (approximately the double in length), therefore approximately half of those values should be used for a comparison.

An intriguing and poorly understood aspect about the structural evolution in the study area is the high elevation and low topographic relief observed in the Bogota Savanna. These two features may indicate that a brittle deformation was not the principal mechanism that formed this highland. Similar to the two above discussed works, in our evolutionary model it was necessary to apply a sub vertical displacement to the northwest portion of the study area (i.e., Bogota Savanna). In such a way, it was possible to relate the thermal information from samples A20 and A21 to the structural evolution of this area. The structural analysis presented here suggests that the plateau formation was coincident with the initial period of slow compressive deformation from $\sim 33$ to $\sim 11 \mathrm{Ma}$, in which the shortening velocity was approximately $\sim 160 \mathrm{~m} / \mathrm{Myr}$ (Figure 17A). Carrillo et al. (2016) dismissed the possibility of uplift by brittle deformations only such as fault-related folding (e.g., Mora et al., 2008) instead they proposed the idea of pure shear deformation associated to a mid-crust detachment. Below the brittle portion of the continental lithosphere $(\sim 25 \mathrm{~km})$ underlies the mid-lower crust (Molnar, 1988) which is characterized as being aseismic, and where the deformation may be produced by ductile processes (Allen and Allen, 2006). This ductile deformation zone has been mentioned in numerous studies associated with levels of detachments of mayor upper crustal faults (e.g., Kusznir and Park, 1987; Allen and Allen,
2006). Chamberlin (1910), proposed that the area of material in a fold that is uplifted by deformation (excess area) is equal to the product of the displacement and the depth to the detachment. Therefore, by dividing the excess area by the shortening, it is possible to obtain an estimation of the detachment depth. In this restoration, at $11 \mathrm{Ma}$ the excess area below the Bogota Savanna plateau is approximately $150 \mathrm{~km}^{2}$, and the shortening is $\sim 4.6 \mathrm{~km}$; therefore the estimated mid-crust detachment may be located below $\sim 30 \mathrm{~km}$. The result of this equation may support the hypothesis of pure shear deformation proposed by Carrillo et al. (2016); however, there is a level of uncertainty in this result since the method has failed in other geological settings. The limitations of this equation have been widely discussed by numerous authors (e.g., Bucher, 1933; Kusznir and Park, 1987; Mitra and Namson, 1989; Groshong and Epard, 1994; Epard and Groshong, 1995), nevertheless, here it appears to produce a reasonable first-order result. Additionally, evidence of homogeneous flattening and strain associated with pure shear has been presented in this area previously (e.g., Kammer, 1997; Kammer and Mora, 1999; Mora and Kammer, 1999; Kammer et al., 2020). Therefore, it is possible to infer that Bogota Savanna plateau formed, during the early stage (from $\sim 33 \mathrm{Ma}$ to $\sim 11 \mathrm{Ma}$ ), primarily by a ductile mechanism caused by the slow-deformation rate. Then, the rapid shortening velocity (from $\sim 11 \mathrm{Ma}$ to Recent) resulted in brittle deformation primarily located in the frontal system and foreland basin, where the structural relief can be explained by the amount of shortening.

Mora-Páez et al. (2016) used GPS velocities to calculate a shortening rate of $\sim 4000 \mathrm{~m} / \mathrm{Myr}$ for the east and west portion of the Eastern Cordillera. Hence, we can estimate approximately $\sim 2000 \mathrm{~m} / \mathrm{Myr}$ just for the eastern portion. This estimated rate is in the same order of magnitude as the $\sim 2200 \mathrm{~m} / \mathrm{Myr}$ calculated in our sections from $\sim 11$ Ma to Recent. However, $\sim 2000 \mathrm{~m} / \mathrm{Myr}$ is considerably high compared to the $\sim 550 \mathrm{~m} / \mathrm{Myr}$ calculated here from $\sim 33 \mathrm{Ma}$ to Recent (total compressive period). Mora-Páez et al. (2016), also suggest that very young ages of deformation and low total amounts of shortening do not explain the modern GPS rates and crustal thicknesses (Poveda et al., 2015). Perhaps our shortening estimates are too low to be compared to the published estimates (Mora-Páez et al., 2016); however, if the above mentioned ductile deformation is considered, the shortening in our cross-sections could be higher. The evidences discussed here and previous researches (Mora-Páez et al., 2016) indicate that it is unlikely a Late Neogene onset of deformation in the study area.

\section{CONCLUSION}

This research proposes a comprehensive and multidisciplinary methodology to provide insights into the structural evolution of an active fold-and-thrust belt where other approaches cannot be applied (e.g., restoration guided by the growth strata). The method presented here was applied in the Eastern Cordillera of Colombia with the following outcomes.

With approximately $18 \mathrm{~km}$ of shortening, the study area experienced post-rift subsidence during the Paleocene - Eocene 
( $\sim 65 \mathrm{Ma}$ to $\sim 33 \mathrm{Ma}$ ) followed by positive inversion from the Oligocene to Recent ( $\sim 33 \mathrm{Ma}$ o $\sim 0 \mathrm{Ma})$. During the tectonic inversion, the shortening rate increased. The compressional deformation initiated with low shortening rate $(\sim 650 \mathrm{~m} / \mathrm{Myr})$, which increased to $\sim 2200 \mathrm{~m} / \mathrm{Myr}$ to the Present-day. For the total amount of shortening, the deformation velocity could be considered relatively low. In particular, the low initial shortening, which has been also documented in previous studies, gives further evidence of an early ductile deformation in the study area.

The abundant evidence discussed here, regarding the timing of deformation, favors a Paleogene to Early Neogene onset of shortening and deformation along the eastern side of the Eastern Cordillera and discard a younger (Late Neogene) timings for the onset of deformation.

\section{REFERENCES}

Allen, P. A., and Allen, J. R. (2006). Basin analysis: principles and application to petroleum play assessment. Hoboken, New Jersey, US: Blackwell Science Ltd.

Allmendinger, R. W. (2015). Modern structural practice. 293, 2015 Available at: http://www.geo.cornell.edu/geology/faculty/RWA/structure-lab-manual/.

Almendral, A., Robles, W., Parra, M., Mora, A., Ketcham, R., and Raghib, M. (2015). FetKin: coupling kinematic restorations and temperature to predict thrusting, exhumation histories, and thermochronometric ages. AAPG Bull. 99, 1557-1573. doi:10.1306/07071411112

Anderson, V. J., Horton, B. K., Saylor, J. E., Mora, A., Tesón, E., Breecker, D. O., et al. (2016). Andean topographic growth and basement uplift in southern Colombia: implications for the evolution of the Magdalena, Orinoco, and Amazon river systems. Geosphere 12, 1235-1256. doi:10.1130/ges01294.1

Anderson, V. J., Saylor, J. E., Shanahan, T. M., and Horton, B. K. (2015). Paleoelevation records from lipid biomarkers: application to the tropical Andes. Geol. Soc. Am. Bull. 127, 1604-1616. doi:10.1130/b31105.1

Armstrong, P. A., Ehlers, T. A., Chapman, D. S., Farley, K. A., and Kamp, P. J. J. (2003). Exhumation of the central Wasatch Mountains, Utah: 1. Patterns and timing of exhumation deduced from low-temperature thermochronology data. J. Geophys. Res. Solid Earth J. Geophys. Res. Solid Earth 108, 2172. doi:10.1029/ 2001jb001708

Bayona, G., Cortes, M., Jaramillo, C., Ojeda, G., Aristizabal, J. J., and Reyes-Harker, A. (2008). An integrated analysis of an orogen-sedimentary basin pair: latest Cretaceous-Cenozoic evolution of the linked Eastern Cordillera orogen and the Llanos foreland basin of Colombia. Geol. Soc. Am. Bull. 120, 1171-1197. doi:10. $1130 / \mathrm{b} 26187.1$

Bilotti, F., Shaw, J. H., Cupich, R. M., and Lakings, R. M. (2005). "Detachment fold, Niger delta," in Seismic interpretation of contractional fault-related folds: An AAPG seismic atlas - studies in geology. Editors J. H. Shaw, Ch. Connors, and J. Suppe (Tulsa, Oklahoma, US: American Association of Petroleum Geologists), 53, 103-104.

Blythe, A. E., Burbank, D. W., Carter, A., Schmidt, K., and Putkonen, J. (2007). Plio-Quaternary exhumation history of the central Nepalese Himalaya: 1. Apatite and zircon fission track and apatite [U-Th]/He analyses. Tectonics 26, TC3002. doi:10.1029/2006tc001990

Braun, J. (2003). Pecube: a new finite-element code to solve the 3D heat transport equation including the effects of a time-varying, finite amplitude surface topography. Comput. Geosci. 29, 787-794. doi:10.1016/s0098-3004(03) 00052-9

Bucher, W. H. (1933). The deformation of the earth's crust. Princeton, New Jersey, US: Princeton University Press, 518.

Butler, R. W. H. (2020). Syn-kinematic strata influence the structural evolution of emergent fold-thrust belts. Geol. Soc. Lond. Spec. Publ. 490, 57-78. doi:10.1144/ sp490-2019-14

Cao, K., Bernet, M., Wang, G.-C., van der Beek, P., Wang, A., Zhang, K. X., et al. (2013). Focused pliocene-quaternary exhumation of the eastern pamir domes,

\section{DATA AVAILABILITY STATEMENT}

The original contributions presented in the study are included in the article/Supplementary Material, further inquiries can be directed to the corresponding author.

\section{AUTHOR CONTRIBUTIONS}

DC compiled, classified, and interpreted the data. Afterward, he performed the structural-evolution model and analysis presented here. DP has significantly contributed with his knowledge about the kinematics and mechanisms of fold-and-thrust belts. AM shared his broad experience and learning about the Eastern Cordillera of Colombia to clarify the critical aspects of this work.

western China. Earth Planet. Sci. Lett. 363, 16-26. doi:10.1016/j.epsl.2012. 12.023

Carrillo, E., Mora, A., Ketcham, R. A., Amorocho, R., Parra, M., Costantino, D., et al. (2016). Movement vectors and deformation mechanisms in kinematic restorations: a case study from the Colombian eastern cordillera. Interpretation 4, T31-T48. doi:10.1190/int-2015-0049.1

Chamberlin, R. T. (1910). The Appalachian folds of central Pennsylvania. J. Geol. 18, 228-251. doi:10.1086/621722

Colletta, B., Hebrard, F., Letouzey, J., Werner, P., and Rudkiewicz, J. L. (1990). "Tectonic style and crustal structure of the Eastern Cordillera (Colombia) from a balanced cross-section," in Petroleum and tectonics in mobile belts. Editor J. Letouzey (Paris, France: Editions Technip), 81-100.

Cooper, M. A., Addison, F. T., Alvarez, R., Coral, M., Graham, R., Hayward, A. B., et al. (1995). Basin development and tectonic history of the Llanos basin, eastern Cordillera, and middle Magdalena Valley, Colombia. AAPG Bull. 79, 1421-1442.

Cooper, M. (2007). "Structural style and hydrocarbon prospectivity in fold and thrust belts; a global review," in Deformation of the continental crust: the legacy of mike coward. Editors A. C. Ries, R. W. H. Butler, and R. H. Graham (London: Geological Society, London, Special Publications), 272, 447-472.

DeCelles, P. G., and Giles, K. A. (1996). Foreland basin systems. Basin Res. 8, 105-123. doi:10.1046/j.1365-2117.1996.01491.x

Dickinson, W. R., and Suczek, C. A. (1979). Plate tectonics and sandstone compositions. AAPG Bull. 63, 2164-2182. doi:10.1306/2F9188FB-16CE11D7-8645000102C1865D

Ehlers, T. A., Willett, S. D., Armstrong, P. A., and Chapman, D. S. (2003). Exhumation of the central Wasatch Mountains, Utah: 2. Thermokinematic model of exhumation, erosion, and thermochronometer interpretation. J. Geophys. Res. Solid Earth 108, 2173. doi:10.1029/2001jb001723

Eichelberger, N., McQuarrie, N., Ryan, J., Karimi, B., Beck, S., and Zandt, G. (2015). Evolution of crustal thickening in the central Andes, Bolivia. Earth Planet. Sci. Lett. 426, 191-203. doi:10.1016/j.epsl.2015.06.035

England, P., and Molnar, P. (1990). Surface uplift, uplift of rocks, and exhumation of rocks. Geology 18, 1173-1177. doi:10.1130/0091-7613(1990)018<1173: suuora $>2.3 . \mathrm{co} ; 2$

Epard, J.-L., and Groshong, R. H., Jr. (1995). Kinematic model of detachment folding including limb rotation, fixed hinges and layer-parallel strain. Tectonophysics 247, 85-103. doi:10.1016/0040-1951(94)00266-c

Erslev, E. A. (1991). Trishear fault-propagation folding. Geology 19, 617-620. doi:10.1130/0091-7613(1991)019<0617:tfpf $>2.3 . c 0 ; 2$

Fitzgerald, P. G., Sorkhabi, R. B., Redfield, T. F., and Stump, E. (1995). Uplift and denudation of the central Alaska Range: a case study in the use of apatite fission track thermochronology to determine absolute uplift parameters. J. Geophys. Res. 100, 20175-20191. doi:10.1029/95jb02150

Fleischer, R. L., Price, P. B., and Walker, R. M. (1975). Nuclear tracks in solids: principles and applications. Berkeley, California, US: University of California Press, 605.

Garver, J. I., Brandon, M. T., Roden-Tice, M., and Kamp, P. J. J. (1999). "Exhumation history of orogenic highlands determined by detrital fissiontrack thermochronology," in Exhumation processes: normal faulting, ductile 
flow and erosion. Editors U. Ring, M. T. Brandon, G. S. Lister, and S. D. Willett (London: Geological Society, London, Special Publication), 154, 283-304.

Garver, J. I., and Kamp, P. J. J. (2002). Integration of zircon color and zircon fissiontrack zonation patterns in orogenic belts: application to the Southern Alps, New Zealand. Tectonophysics 349, 203-219. doi:10.1016/s0040-1951(02) 00054-9

Garver, J. I., Reiners, P. W., Walker, L. J., Ramage, J. M., and Perry, S. E. (2005). Implications for timing of andean uplift from thermal resetting of radiationdamaged zircon in the Cordillera huayhuash, northern Peru. J. Geology. 113, 117-138. doi:10.1086/427664

Green, P. F., Duddy, I. R., Gleadow, A. J. W., Tingate, P. R., and Laslett, G. M. (1986). Thermal annealing of fission tracks in apatite. Chem. Geology. Isotope Geosci. Sec. 59, 237-253. doi:10.1016/0168-9622(86)90074-6

Groshong, R. H., Jr., and Epard, J. L. (1994). The role of strain in area-constant detachment folding. J. Struct. Geol. 16, 613-618. doi:10.1016/0191-8141(94) 90113-9

Hooghiemstra, H., and Cleef, A. M. (1995). "Pleistocene climatic change and environmental and generic dynamics in the north Andean montane forest and paramo," in Biodiversity and conservation of neotropical montane forests. Editors S. P. Churchill, H. Balslev, and J. L. Luteyn (New York: Memoirs of the New York Botanical Garden), 78, 35-49.

Hooghiemstra, H., Wijninga, V. M., and Cleef, A. M. (2006). The paleobotanical record of Colombia: implications for biogeography and Biodiversity1. Ann. Mo. Bot. Garden 93, 297-325. doi:10.3417/0026-6493(2006)93[297:tproci]2.0.co;2

Horton, B. K., Saylor, J. E., Nie, J., Mora, A., Parra, M., Reyes-Harker, A., et al. (2010). Linking sedimentation in the northern Andes to basement configuration, Mesozoic extension, and Cenozoic shortening: evidence from detrital zircon U-Pb ages, Eastern Cordillera, Colombia. Geol. Soc. Am. Bull. 122, 1423-1442. doi:10.1130/b30118.1

Huerta, A. D., and Rodgers, D. W. (2006). Constraining rates of thrusting and erosion: insights from kinematic thermal modeling. Geology 34, 541-544. doi:10.1130/g22421.1

International Hydrographic Organization (2003). Centenary edition of the GEBCO digital atlas, published on CD-ROM on behalf of the intergovernmental oceanographic commission and the international hydrographic organization as part of the general bathymetric chart of the oceans. Liverpool, U.K: British Oceanographic Data Centre.

Kammer, A. (1997). Los pliegues del sinclinal de tunja. an lisis estructural y modelamiento geom trico. Geolog; a Colomb. 22, 3-25.

Kammer, A., and Mora, A. (1999). Structural style and amount of shortening of the folded Bogotá segment, Eastern Cordillera of Colombia. Zentralblatt fuer Geol. Palaeontol., Teil I, 823-838.

Kammer, A., Piraquive, A., Gomez, C., Mora, A., and Velazquez, A. (2020). "Structural styles of the eastern Cordillera of Colombia," in The geology of Colombia, volume 3 Paleogene - Neogene. Servicio Geológico Colombiano, Publicaciones Geológicas Especiales. Editors J. Gómez and D. Mateus-Zabala (Servicio Geológico Colombiano), 37.

Kusznir, N. J., and Park, R. G. (1987). "The extensional strength of the continental lithosphere: its dependence on geothermal gradient, and crustal composition and thickness," in Continental extensional tectonics. Editors M. P. Coward, J. F. Dewey, and P. L. Hancock (London: Geological Society, London, Special Publications), 28, 35-52.

Lisker, F., Ventura, B., and Glasmacher, U. A. (2009). "Apatite thermochronology in modern geology," in From palaeotemperature constraints to landscape evolution models. Editors F. Lisker, B. Ventura, and U. A. Glasmacher (London: Geological Society, London, Special Publications), 324, 1-23.

Lock, J., and Willett, S. (2008). Low-temperature thermochronometric ages in foldand-thrust belts. Tectonophysics 456, 147-162. doi:10.1016/j.tecto.2008.03.007

Martinez, J. A. (2006). Structural evolution of the Llanos foothills, eastern Cordillera, Colombia. J. South Am. Earth Sci. 21, 510-520. doi:10.1016/j. jsames.2006.07.010

Masini, M., Bigi, S., Poblet, J., Bulnes, M., Cuia, R. D., and Casabianca, D. (2011). "Kinematic evolution and strain simulation, based on cross-section restoration, of the Maiella Mountain: an analogue for oil fields in the Apennines (Italy)," in Kinematic evolution and structural styles of fold-and-Thrust belts. Editors J. Poblet and R. J. Lisle (London: Geological Society, London, Special Publications), 349, 25-44.
McClay, K., Tamara, J., Hammerstein, J., Mora, A., Zamora, G., and Uzkeda, H. (2018). "Sub-andean thick and thin-skinned thrust systems of southeastern Peru and Bolivia-a review," in Petroleum basins and hydrocarbon potential of the Andes of Peru and Bolivia. Editors G. Zamora, K. R. McClay, and V. A. Ramos (Tulsa, Oklahoma, US: AAPG), 117.

McQuarrie, N., and Ehlers, T. A. (2015). Influence of thrust belt geometry and shortening rate on thermochronometer cooling ages: insights from thermokinematic and erosion modeling of the Bhutan Himalaya. Tectonics Tectonics 34, 1055-1079. doi:10.1002/2014TC003783

McQuarrie, N., and Ehlers, T. A. (2017). "Techniques for understanding fold-andthrust belt kinematics and thermal evolution," in Linkages and feedbacks in orogenic systems. Editors R. D. Law, J. R. Thigpen, A. J. Merschat, and H. H. Stowell (Boulder, Colorado, US: Geological Society of America Memoir), 213, 1-30.

Michael, A. (2008). Oxford dictionary of Earth sciences. Oxford, England: Oxford University Press, 654.

Mitra, S., and Namson, J. S. (1989). Equal-area balancing. Am. J. Sci. 289, 563-599. doi:10.2475/ajs.289.5.563

Molnar, P. (1988). Continental tectonics in the aftermath of plate tectonics. Nature 335, 131-137. doi:10.1038/335131a0

Molnar, P., and England, P. (1990). Late Cenozoic uplift of mountain ranges and global climate change: chicken or egg?. Nature 346, 29-34. doi:10.1038/ $346029 \mathrm{a} 0$

Mora, A., Parra, M., Strecker, M. R., Kammer, A., Dimaté, C., and Rodríguez, F. (2006). Cenozoic contractional reactivation of Mesozoic extensional structures in the Eastern Cordillera of Colombia. Tectonics 25, TC2010. doi:10.1029/ $2005 \mathrm{tc} 001854$

Mora, A., Parra, M., Strecker, M. R., Sobel, E. R., Hooghiemstra, H., Torres, V., et al. (2008). Climatic forcing of asymmetric orogenic evolution in the Eastern Cordillera of Colombia. Geol. Soc. Am. Bull. 120, 930-949. doi:10.1130/b26186.1

Mora, A., Gaona, T., Kley, J., Montoya, D., Parra, M., Quiroz, L. I., et al. (2009). The role of inherited extensional fault segmentation and linkage in contractional orogenesis: a reconstruction of Lower Cretaceous inverted rift basins in the Eastern Cordillera of Colombia. Basin Res. 21, 111-137. doi:10.1111/j.13652117.2008.00367.x

Mora, A., Parra, M., Strecker, M. R., Sobel, E. R., Zeilinger, G., Jaramillo, C., et al. (2010). The eastern foothills of the Eastern Cordillera of Colombia: an example of multiple factors controlling structural styles and active tectonics. Geol. Soc. Am. Bull. 122, 1846-1864. doi:10.1130/b30033.1

Mora, A., Blanco, V., Naranjo, J., Sanchez, N., Ketcham, R. A., Rubiano, J., et al. (2013). On the lag time between internal strain and basement involved thrust induced exhumation: the case of the Colombian Eastern Cordillera. J. Struct. Geol. 52, 96-118. doi:10.1016/j.jsg.2013.04.001

Mora, A. S., Reyes-Harker, A. S., Rodriguez, G., Tes $₫$ n, E., Ramirez-Arias, J. C., Parra, M., et al. (2013). "Inversion tectonics under increasing rates of shortening and sedimentation: cenozoic example from the eastern cordillera of Colombia," in Thick-skin-dominated orogens: from initial inversion to full accretion. Editors M. Nemcok, A. Mora, and W. Cosgrove (London: Geological Society, London, Special Publications), 377, 411-442.

Mora, A., Ketcham, R. A., Higuera-Díaz, I. C., Bookhagen, B., Jimenez, L., and Rubiano, J. (2014). formation of passive-roof duplexes in the Colombian subandes and perú. Lithosphere 6, 456-472. doi:10.1130/1340.1

Mora, A., Parra, M., Forero, G. R., Blanco, V., Moreno, N., Caballero, V., et al. (2015a). "What drives orogenic asymmetry in the Northern Andes?: a case study from the apex of the Northern Andean Orocline," in Petroleum geology and potential of the Colombian caribbean margin. Editors C. Bartolini and P. Mann (Tulsa, Oklahoma, United States: AAPG Memoir), 108, 547-586.

Mora, A., Casallas, W., Ketcham, R. A., Gomez, D., Parra, M., Namson, J., et al. (2015b). Kinematic restoration of contractional basement structures using thermokinematic models: a key tool for petroleum system modeling. Bulletin 99, 1575-1598. doi:10.1306/04281411108

Mora, A. S., and Kammer, A. (1999). Comparacion de los estilos estructurales en la seccion entre Bogota y los Farallones de Medina, Cordillera Oriental de Colombia. Geolog; a Colomb., 24, 55-82.

Mora, A., and Parra, M. (2008). The structural style of footwall shortcuts along the eastern foothills of the Colombian Eastern Cordillera: differences with other inversion-related structures. C.T.F - Cienc. Tecnol. Futuro 3, 7-21. 
Mora-Páez, H., Mencin, D. J., Molnar, P., Diederix, H., Cardona-Piedrahita, L., Peláez-Gaviria, J.-R., et al. (2016). GPS velocities and the construction of the eastern cordillera of the Colombian Andes. Geophys. Res. Lett. 43, 8407-8416. doi:10.1002/2016gl069795

Nemcok, M., Schamel, S., and Gayer, R. (2005). Thrustbelts. Structural architecture, thermal regimes, and petroleum systems. Cambridge: Cambridge University Press, 541.

Parra, M., Mora, A., Sobel, E. R., Strecker, M. R., and González, R. (2009a). Episodic orogenic front migration in the northern Andes: constraints from lowtemperature thermochronology in the Eastern Cordillera, Colombia. Tectonics 28, a. doi:10.1029/2008tc002423

Parra, M., Mora, A., Jaramillo, C., Strecker, M. R., Sobel, E. R., Quiroz, L., et al. (2009b). Orogenic wedge advance in the northern Andes: evidence from the oligocene-miocene sedimentary record of the Medina Basin, eastern Cordillera, Colombia. Geol. Soc. Am. Bull. 121, 780-800. doi:10.1130/b26257.1

Parra, M., Mora, A., Jaramillo, C., Torres, V., Zeilinger, G., and Strecker, M. R. (2010). Tectonic controls on Cenozoic foreland basin development in the north-eastern Andes, Colombia. Basin Res. 22, 874-903. doi:10.1111/j.13652117.2009.00459.x

Parra, M., Mora, A., Lopez, C., Ernesto Rojas, L., and Horton, B. K. (2012). Detecting earliest shortening and deformation advance in thrust belt hinterlands: example from the Colombian Andes. Geology 40, 175-178. doi:10.1130/g32519.1

Poblet, J., McClay, K., Storti, F., and Muñoz, J. A. (1997). Geometries of syntectonic sediments associated with single-layer detachment folds. J. Struct. Geol. 19, 369-381. doi:10.1016/s0191-8141(96)00113-7

Poveda, E., Monsalve, G., and Vargas, C. A. (2015). Receiver functions and crustal structure of the northwestern Andean region, Colombia. J. Geophys. Res. Solid Earth 120, 2408-2425. doi:10.1002/2014jb011304

Quintero, I. (2010). Cinematica de Las estructuras de deformacion del sector norte de La cuenca de Medina (Colombia), durante La depositacion del grupo Guayabo. MSc thesis. Bucaramanga, Santander: Universidad Industrial de Santander, Escuela De Geologia, 83.

Ramirez-Arias, J. C., Mora, A., Rubiano, J., Duddy, I., Parra, M., Moreno, N., et al. (2012). The asymmetric evolution of the Colombian Eastern Cordillera. Tectonic inheritance or climatic forcing? New evidence from thermochronology and sedimentology. J. South Am. Earth Sci. 39, 112-137. doi:10.1016/j.jsames.2012.04.008

Reiners, P. W., and Brandon, M. T. (2006). Using thermochronology to understand orogenic erosion. Annu. Rev. Earth Planet. Sci. 34, 419-466. doi:10.1146/ annurev.earth.34.031405.125202

Rowan, M. G., and Linares, R. (2000). Fold-evolution matrices and axial-surface analysis of fault-bend folds: application to the medina anticline, Eastern Cordillera, Colombia. AAPG Bull. 84, 741-764.

Rowan, M. G., and Peel, F. J. (2005). "Mississippi fan fold belt, gulf of Mexico," in Seismic interpretation of contractional fault-related folds. An AAPG seismic atlas - studies in geology. Editors J. H. Shaw, C. D. Connors, and J. Suppe (Tulsa, Oklahoma, US: AAPG), 53, 104-109.

Sarmiento-Rojas, L. F., Van Wess, J. D., and Cloetingh, S. (2006). Mesozoic transtensional basin history of the Eastern Cordillera, Colombian Andes: inferences from tectonic models. J. South Am. Earth Sci. 21, 383-411. doi:10.1016/j.jsames.2006.07.003

Saylor, J. E., Horton, B. K., Stockli, D. F., Mora, A., and Corredor, J. (2012a). Structural and thermochronological evidence for Paleogene basement-involved shortening in the axial Eastern Cordillera, Colombia. J. South Am. Earth Sci. 39, 202-215. doi:10.1016/j.jsames.2012.04.009

Saylor, J. E., Stockli, D. F., Horton, B. K., Nie, J., and Mora, A. (2012b). Discriminating rapid exhumation from syndepositional volcanism using detrital zircon double dating: implications for the tectonic history of the Eastern Cordillera, Colombia. Geol. Soc. Am. Bull. 124, 762-779. doi:10.1130/b30534.1

Segovia, A. (1965). Mapa Geol gico de la plancha L-12 (Medina) de la Rep£blica de Colombia. Bogota', Colombia: Serv. Geol. Nac.

Shaw, J. H., Connors, C., and Suppe, J. (2005). Seismic interpretation of contractional fault-related folds: an AAPG seismic atlas. Tulsa, Oklahoma: AAPG Studies in Geology, 156.

Suppe, J., and Medwedeff, D. A. (1990). Geometry and kinematics of faultpropagation folding. Eclogae Geol. Helv. 83, 409-454.
Tagami, T. (2005). "Zircon fission-track thermochronology and applications to fault studies," in Low-temperature thermochronology, techniques, interpretation, and applications. Editors P. W. Reiners and T. A. Ehlers (Chantilly, Virginia: Mineralogical Society of America), 58, 95-122.

Tamara, J., Mora, A., Robles, W., Kammer, A., Ortiz, A., Sanchez-Villar, N., et al. (2015). Fractured reservoirs in the Eastern Foothills, Colombia, and their relationship with fold kinematics. Bulletin 99, 1599-1633. doi:10.1306/ 09291411109

Teixell, A., Ruiz, J.-C., Teson, E., and Mora, A. (2015). “The structure of an inverted back-arc rift: insights from a transect across the Eastern Cordillera of Colombia near Bogotá," in Petroleum geology and potential of the Colombian Caribbean Margin. Editors C. Bartolini and P. Mann.

Ter Voorde, M., De Bruijne, C. H., Cloetingh, S. A. P. L., and Andriessen, P. A. M. (2004). Thermal consequences of thrust faulting: simultaneous versus successive fault activation and exhumation. Earth Planet. Sci. Lett. 223, 395-413. doi:10.1016/j.epsl.2004.04.026

Tesón, E., Mora, a., Silva, A., Namson, J., Teixell, A., Castellanos, J., et al. (2013). "Relationship of Mesozoic graben development, stress, shortening magnitude, and structural style in the Eastern Cordillera of the Colombian Andes," in Thick-skin-dominated orogens: from initial inversion to full accretion. Editors M. Nemcok, A. Mora, and J. W. Cosgrove (London: Geological Society, London, Special Publications), 377, 257-283.

Torres, V., Vandenberghe, J., and Hooghiemstra, H. (2005). An environmental reconstruction of the sediment infill of the Bogotá basin (Colombia) during the last 3 million years from abiotic and biotic proxies. Palaeogeogr. Palaeoclimatol. Palaeoecol. 226, 127-148. doi:10.1016/j.palaeo.2005.05.005

Ulloa, C., and Rodriguez, E. (1976). Geologia del Cuadrangulo K12, Guateque. Bolet $; n$ Geol. Ingeominas, Bogota, Colombia 12, 3-55.

Van der Hammen, T., Werner, J. H., and van Dommelen, H. (1973). Palynological record of the upheaval of the Northern Andes: a study of the pliocene and lower quaternary of the Colombian Eastern Cordillera and the early evolution of its high-Andean biota. Rev. Palaeobotany Palynol. 16, 1-122. doi:10.1016/00346667(73)90031-6

Veer, R. V. t., and Hooghiemstra, H. (2000). Montane forest evolution during the last $650000 \mathrm{yr}$ in Colombia: a multivariate approach based on pollen record Funza-I. J. Quat. Sci. 15, 329-346. doi:10.1002/1099-1417(200005)15:4<329:: aid-jqs538>3.0.co;2-3

Vidal-Royo, O., Muñoz, J. A., Hardy, S., Koyi, H., and Cardozo, N. (2013). Structural evolution of Pico del Águila anticline (External Sierras, southern Pyrenees) derived from sandbox, numerical and 3D structural modelling techniques. Geol. Acta 11, 1-26. doi:10.1344/105.000001780

Whipp, D. M., Jr., Ehlers, T. A., Braun, J., and Spath, C. D. (2009). Effects of exhumation kinematics and topographic evolution on detrital thermochronometer data. J. Geophys. Res. Earth Surf. 114, F04021. doi:10.1029/ 2008JF001195

Wijninga, V. M. (1996). Palynology and paleobotany of Neogene sediments from the high plain of Bogota (Colombia): evolution of the Andean flora from an ecological perspective. Ph.D. Thesis. Amsterdam: University of Amsterdam, 370.

Williams, G. D., Powell, C. M., and Cooper, M. A. (1989). "Geometry and kinematics of inversion tectonics," in Inversion tectonics. Editors M. A. Cooper and G. D. Williams (London: Geological Society, London, Special Publications), 44, 3-15.

Willis, B., and Willis, R. (1934). Geologic structures. Alapakkam, Chennai: McGraw-Hill, 544.

Conflict of Interest: The authors declare that the research was conducted in the absence of any commercial or financial relationships that could be construed as a potential conflict of interest.

Copyright (c) 2021 Costantino, Paton and Mora. This is an open-access article distributed under the terms of the Creative Commons Attribution License (CC BY). The use, distribution or reproduction in other forums is permitted, provided the original author(s) and the copyright owner(s) are credited and that the original publication in this journal is cited, in accordance with accepted academic practice. No use, distribution or reproduction is permitted which does not comply with these terms. 